HYDROLOGY OF COAL-LEASE AREAS

NEAR DURANGO, COLORADO

By Tom Brooks

U.S. GEOLOGICAL SURVEY

Water-Resources Investigations Report 85-4125

Prepared in cooperation with the

U.S. BUREAU OF LAND MANAGEMENT and the

U.S. FOREST SERVICE

Lakewood, Colorado

1985 
DEPARTMENT OF THE INTERIOR

DONALD P. HODEL, Secretary

U.S. GEOLOGICAL SURVEY

Dallas L. Peck, Director

For additional information write to:

Colorado District Chief U.S. Geological Survey Water Resources Division Box 25046, Mail Stop 415 Denver Federal Center Denver, CO 80225
Copies of this report can be purchased from:

Open-File Services Section Books and Open-File Reports Building 41, Box 25425 Denver Federal Center Denver, CO 80225

Telephone: (303) 236-7476 
Abstract---n-

Introduction---n--

Purpose and scope-1-

Description of study area-n

Data collection-

Acknowledgements

Geology--

Stratigraphy and lithology-

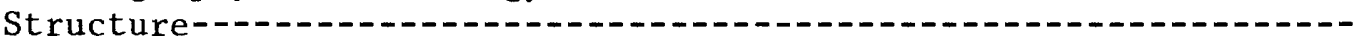

Hydrogeology and ground-water quality--

Bedrock units--

Unconsolidated deposits-1-0

Stollsteimer Creek study area-

Location--

Surface-water characteristics-

Ground-water characteristics-a

Bedrock units---1-n

Alluvium deposits--

Mine development and effects--1.-

Hay Gulch study area--

Location--1-

Surface-water characteristics-1.-

Ground-water characteristics-1-

Bedrock units--

Alluvium deposits-_...- 30

Mine development and effects-1-n 30

Needs for future studies-- 32

Summary and conclusions- 33

Hydrology--_- 33

Mining effects--_- 34

Needs for future studies-_-n 34

References---_- 35

Supplementary Data-- 36 


\section{FIGURES}

Figures 1-5. Maps showing:

Page

1. Location of the Durango study area--_- 3

2. Data-collection sites outside the Stollsteimer

Creek and Hay Gulch study areas--.-- 5

3. Location of well and spring sites in the

Stollsteimer Creek study area--..- 6

4. Location of streamflow-measurement sites in

the Stollsteimer Creek study area-- 7

5. Location of data-collection sites in the Hay Gulch

study area--

6. Diagram of numbering wells, springs, and streamflow-

measurement sites using township, range, and section----- 9

7-8. Maps showing:

7. Hydrogeology of the Durango study area---n 11

8. Location of coal-lease tracts of the Chimney

Rock Mine-.-... 19

9. Map and hydrogeologic section of Stollsteimer

Creek valley-..- 22

10-11. Maps showing:

10. Coal-lease tracts of the National King Coal Mine----- 27

11. Abandoned and future mine areas, National King

Coal Mine-.-. 31

TABLES

Table 1. Chemical analyses of water samples from wells,

springs, and streams-1 37

2. Well information- 41

3. Spring information-- 43

4. Stream and ditch discharge and water-quality data--------- 44 


\section{CONVERSION FACTORS}

The following factors can be used to convert inch-pound units to the International System (SI) of units.

Multiply inch-pound units

cubic foot per second $\left(\mathrm{ft}^{3} / \mathrm{s}\right)$

foot $(\mathrm{ft})$

foot per day $(\mathrm{ft} / \mathrm{d})$

gallon per minute (gal/min)

inch (in.)

mile (mi)

square foot per day $\left(f t^{2} / d\right)$

square mile $\left(\mathrm{mi}^{2}\right)$
By

0.02832

0.3048

0.3048

0.06309

25.40

1.609

0.09290

2.590
To obtain SI units

cubic meter per second meter

meter per day

liter per second

millimeter

kilometer

square meter per day

square kilometer

Temperature can be converted to degree Celsius $\left({ }^{\circ} \mathrm{C}\right)$ or degree Fahrenheit $\left({ }^{\circ} \mathrm{F}\right)$ by the following equations:

$$
\begin{aligned}
& { }^{\circ} \mathrm{C}=9 / 5\left({ }^{\circ} \mathrm{F}-32\right) \\
& { }^{\circ} \mathrm{F}=5 / 9\left({ }^{\circ} \mathrm{C}+32\right)
\end{aligned}
$$

The following water-quality terms and abbreviations also are used in this report:

milligrams per liter $(\mathrm{mg} / \mathrm{L})$. 


\section{HYDROLOGY OF COAL-LEASE AREAS \\ NEAR DURANGO, COLORADO}

By Tom Brooks

\section{ABSTRACT}

The U.S. Bureau of Land Management leases Federal lands and minerals for coal mining near Durango, Colorado. This report addresses the hydrologic suitability of those lands for coal leasing; the report describes the general hydrology of the Durango area and, more specifically, the hydrology of the Stollsteimer Creek study area 32 miles east of Durango and the Hay Gulch study area 12 miles southwest of Durango.

The most productive aquifers in the Durango study area are Quaternary alluvium and the Tertiary Animas Formation. Water wells completed in alluvium typically yield 5 to 20 gallons per minute; wells completed in the Animas Formation yield as much as 50 gallons per minute. Water quality in these aquifers is variable, but it generally is suitable for domestic use.

The coa1-bearing Cretaceous Fruitland and Menefee Formations were mined by surface methods at the Chimney Rock Mine in the Stollsteimer Creek study area and by underground methods at the National King Coal Mine in the Hay Gulch study area. Effects of surface mining in the Stollsteimer Creek area are: (1) Dewatering of an alluvial aquifer; and (2) local degradation of alluvium water quality by spoil-pile effluent. Effects of underground mining in the Hay Gulch area are: (1) Introduction of water with greater dissolvedsolids concentrations into the upper Hay Gulch alluvium from mine runoff; (2) subsidence fracturing which could dewater streams and the alluvial aquifer. 


\section{INTRODUCTION}

Surface and underground coal mines have been operating in parts of Montezuma, La Plata, and Archuleta Counties, Colorado for more than a century (fig. 1). The U.S. Bureau of Land Management has designated parts of these counties as a Known Recoverable Coal Resource Area (KRCRA), and may offer additional coal-mining tracts for leasing.

Surface and ground water may be disturbed by open-pit mining and underground mining. As more coal tracts are leased, the possibility for disruption of existing surface- and ground-water supplies increases. Such disruption is a particular concern in rural areas, where ground water is important for domestic and stock use. Mining may alter recharge and discharge areas, water chemistry, and flow characteristics. During 1983-84, the U.S. Geological Survey, in cooperation with the BLM and U.S. Forest Service, studied the hydrology of the area and assessed the hydrologic effects of present and future coal mining in the area.

\section{Purpose and Scope}

The purpose of this report is to describe the general hydrology of the KRCRA and the hydrology and hydrologic effects of mining in two specific study areas within the KRCRA shown in figure 1: the Stollsteimer Creek area and the Hay Gulch area. The Stollsteimer Creek study area includes a surface mine located in a stream valley, where mining may affect surface water, ground water, and water quality. The Hay Gulch study area includes an underground mine that may cause surface-water losses through subsidence fractures, and may alter ground-water chemistry.

The major study objective was to define the ground- and surface-water characteristics of the specific and general study areas. Specific objectives were to:

1. Prepare a bibliography of previous studies.

2. Define local and regional ground-water flow systems as data permit.

3. Determine surface- and ground-water chemistry in areas proximal to coal mining.

4. Describe the ability of geologic units in the specific study areas to transmit ground water.

5. Determine the potential impacts of coal mining on the hydrologic systems in the specific study areas.

6. List needs for future hydrologic investigations.

The study objectives were met by several methods. Well information and data were obtained from the U.S. Geological Survey, Colorado State Engineer's office, and mining companies. Wells and springs were inventoried and stream discharges were measured. The effects of flooding in Stollsteimer Creek were determined using methods described by McCain and Jarrett (1976). The land surface overlying underground mines was examined for evidence of subsidence. 


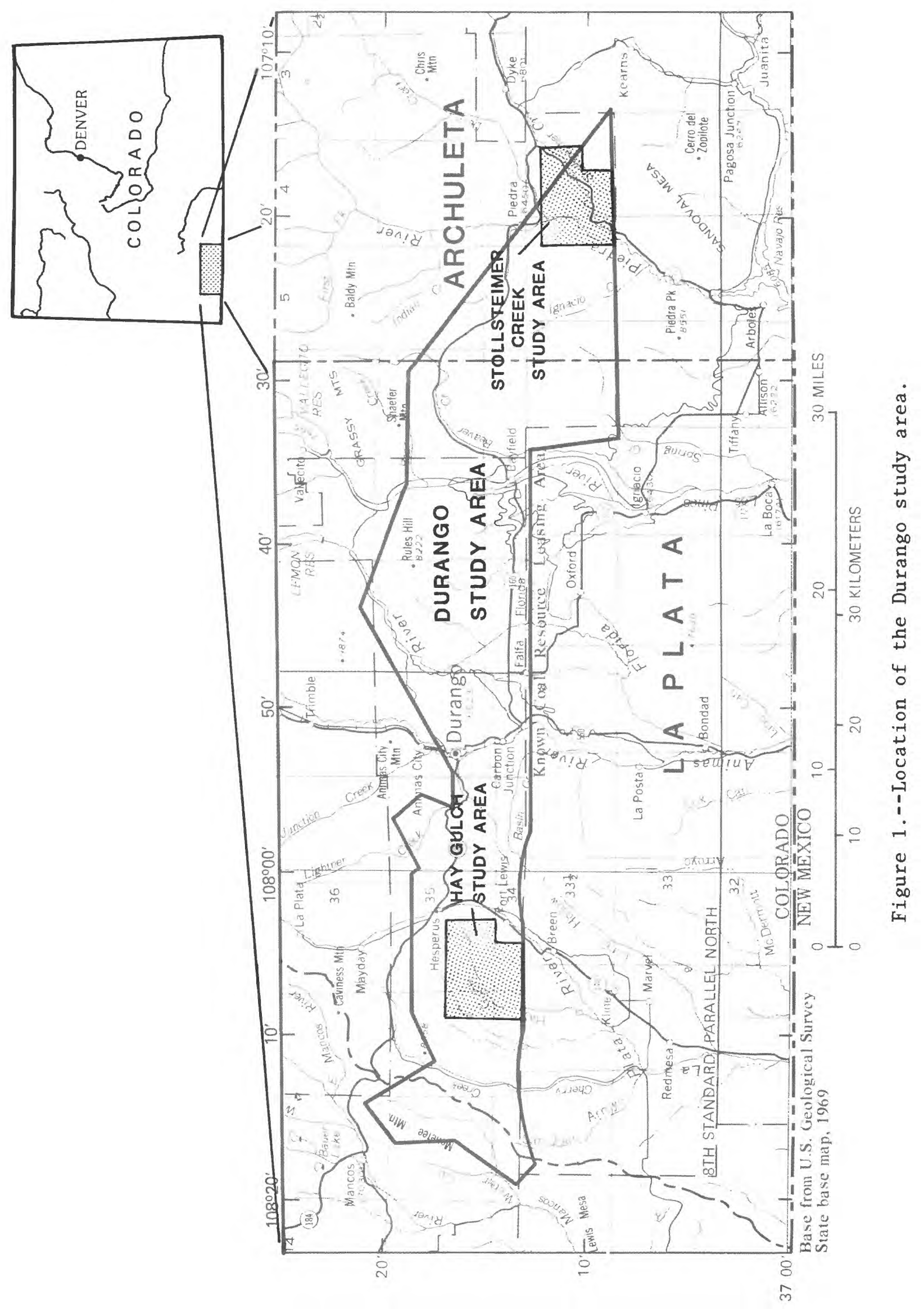




\section{Description of the Study Area}

The KRCRA is approximately $420 \mathrm{mi}^{2}$; it is referred to in this report as the Durango study area (fig. 1). The location of the two smaller study areas in the Durango study area, the Stollsteimer Creek study area (including the Chimney Rock Mine) in Archuleta County and the Hay Gulch study area (including the National King Coal Mine) in La Plata County, also are shown in figure 1. Hydrologic data were collected extensively in these specific areas. Additional data were collected in the larger Durango study area to support an interpretation of hydrologic conditions in the smaller study areas.

The Durango study area comprises parts of eastern Montezuma County, central La Plata County, and western Archuleta County (fig. 1). The Hay Gulch study area is approximately $12 \mathrm{mi}$ southwest of Durango in La Plata County, and the Stollsteimer Creek study area is about $32 \mathrm{mi}$ southeast of Durango in Archuleta County.

The vegetation and topography of the Durango study area is varied. Scrub oak, pinyon pine, and juniper are common in the south and far west. Moderately steep canyons contain ephemeral, seasonal, and perennial streams that generally flow south-southwest. Pinyon pine, scrub oak, juniper, ponderosa pine, and aspen are common in the steeper northern and eastern parts.

Altitudes range from about $6,600 \mathrm{ft}$ near the National King Coal Mine to $8,800 \mathrm{ft}$ northeast of Durango. The area is semiarid, and precipitation ranges from $16 \mathrm{in.}$. in the south to $25 \mathrm{in}$. in the north (McCain and Jarrett, 1976). Mean monthly temperatures at Durango range from $28.3^{\circ} \mathrm{F}$ in January to $69.7^{\circ} \mathrm{F}$ in August. The mean annual temperature is $48.7^{\circ} \mathrm{F}$ (National Climatic Data Center, 1983).

\section{Data Collection}

Hydrologic data in this report include field data collected by the U.S. Geological Survey between March 1983 and November 1983 and data obtained from private companies and from previous studies. Most data were collected in the Stollsteimer Creek and Hay Gulch study areas because these areas currently are mined, and additional mining is expected nearby. Location of data sites are shown in figures 2-5. An explanation of the well-numbering system used in this report is given in figure 6 .

Water chemistry, well, spring, and streamflow data are listed in tables 1-4 in the Supplementary Data section at the back of this report. Site numbers on the map correlate with site numbers in the tables. Water-quality data for 41 wells, 2 springs, and 7 stream sites are given in table 1 . Hydrologic data are given for 52 wells in table 2, including depth-to-water measurements for 49 wells. Hydrologic data for 4 springs are given in table 3. Site descriptions, discharge, temperature, $\mathrm{pH}$, and specificconductance data are given for 24 stream and irrigation-ditch measurement sites in table 4. Data collected at surface-water sites include 89 discharge measurements and 6 water-quality analyses. Streamflow measurements were made on Deep Creek (in Deep Canyon) in August 1983, Stollsteimer Creek in September 1983, and on Cabezon Creek (in Cabezon Canyon) in November 1983. 


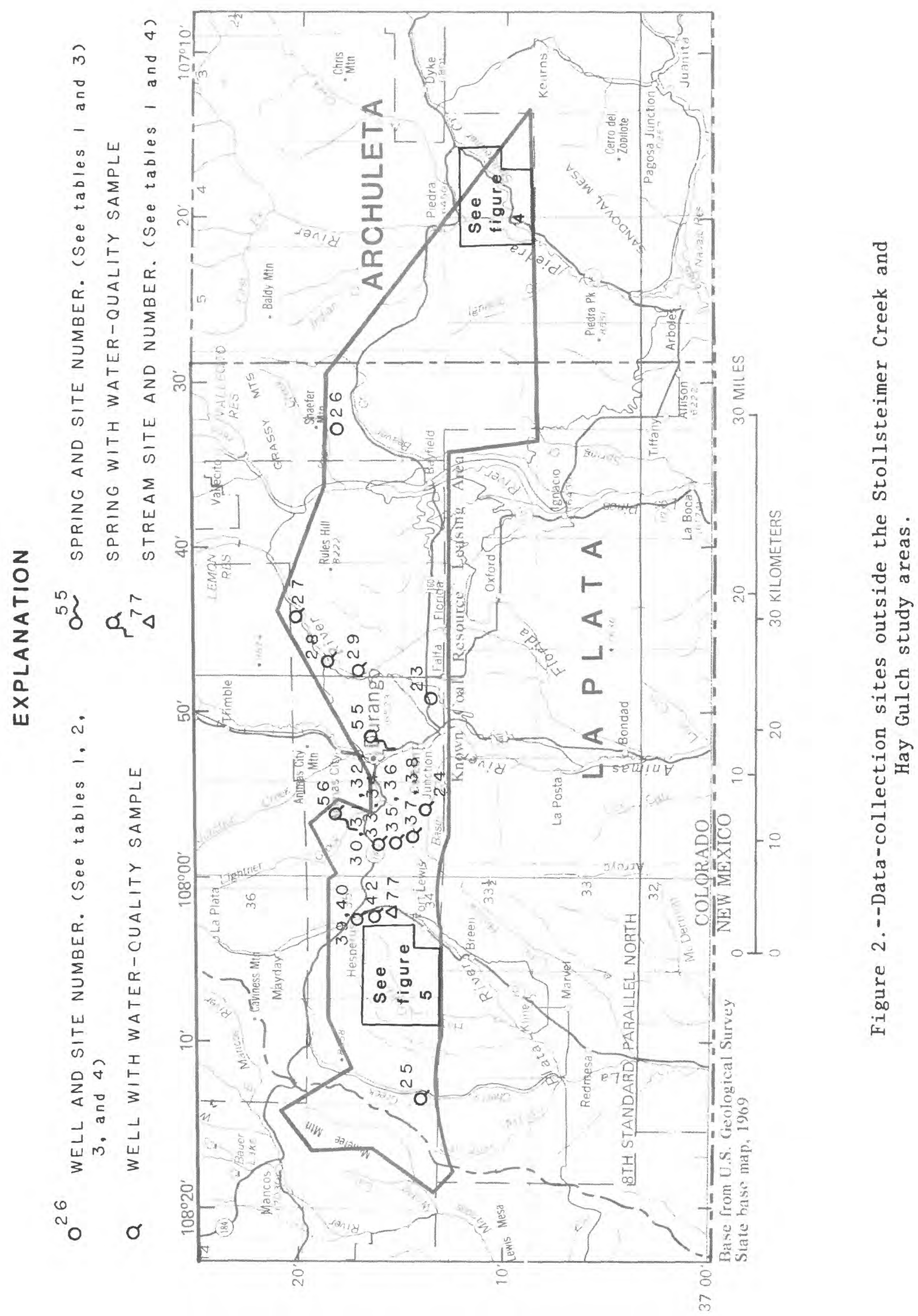




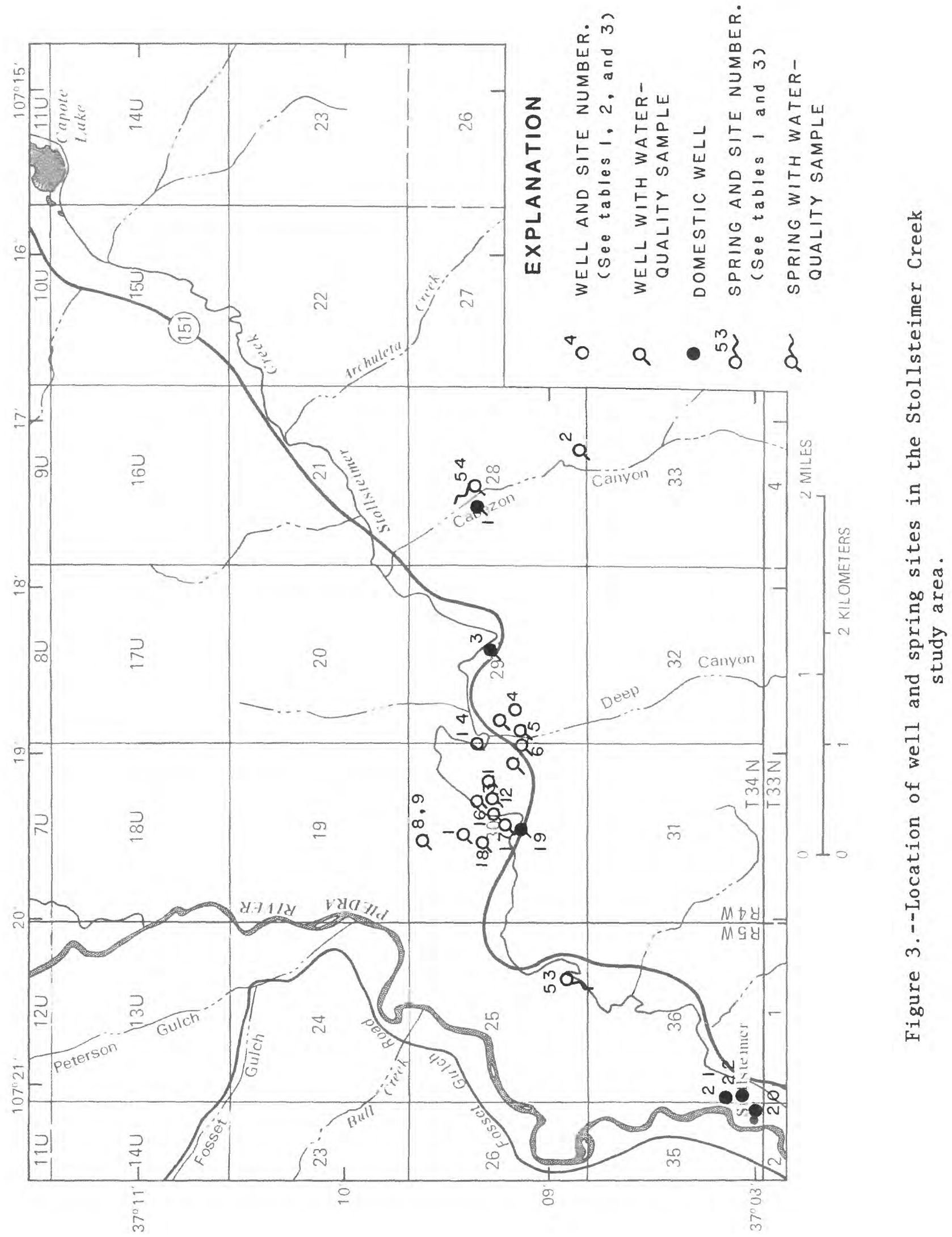




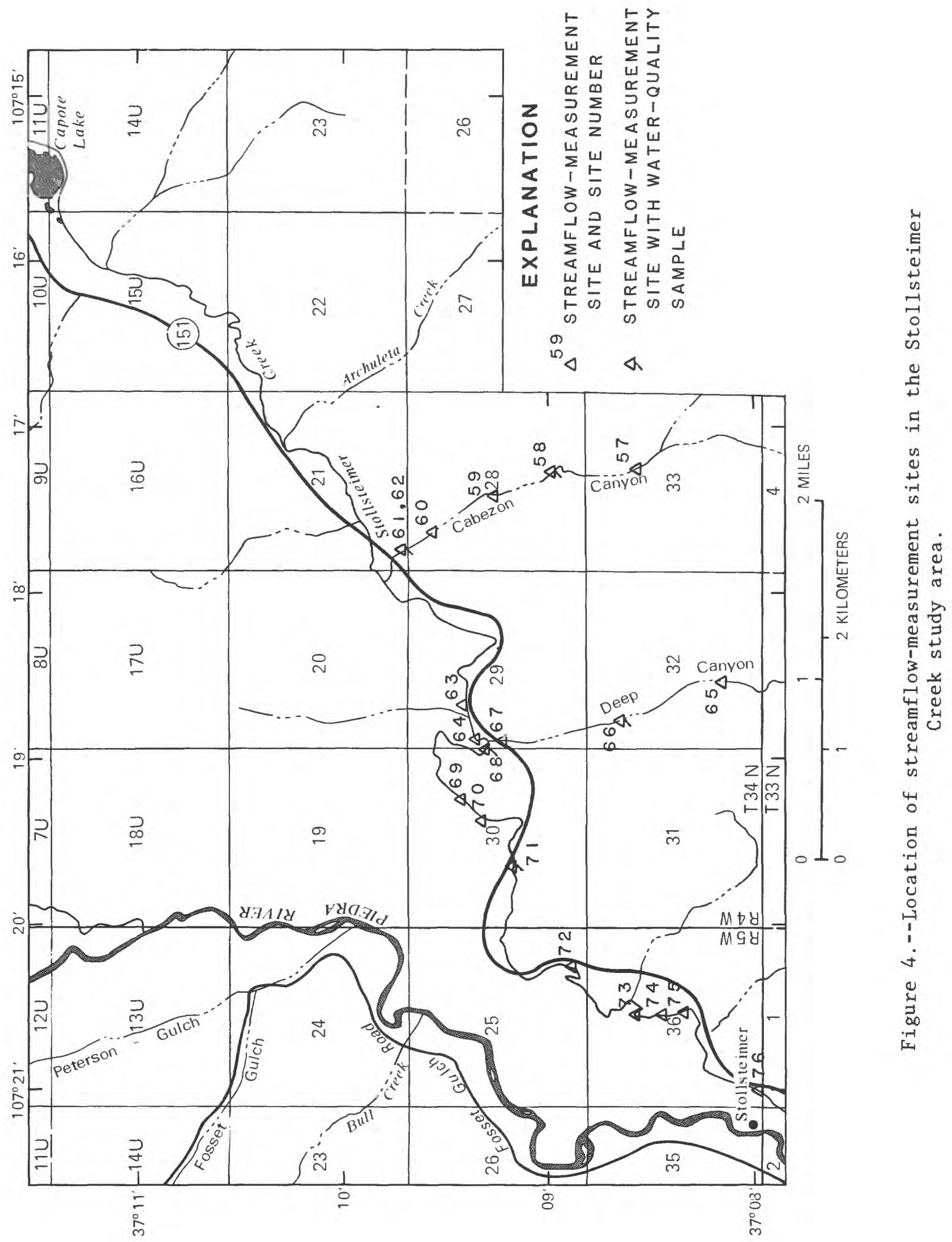




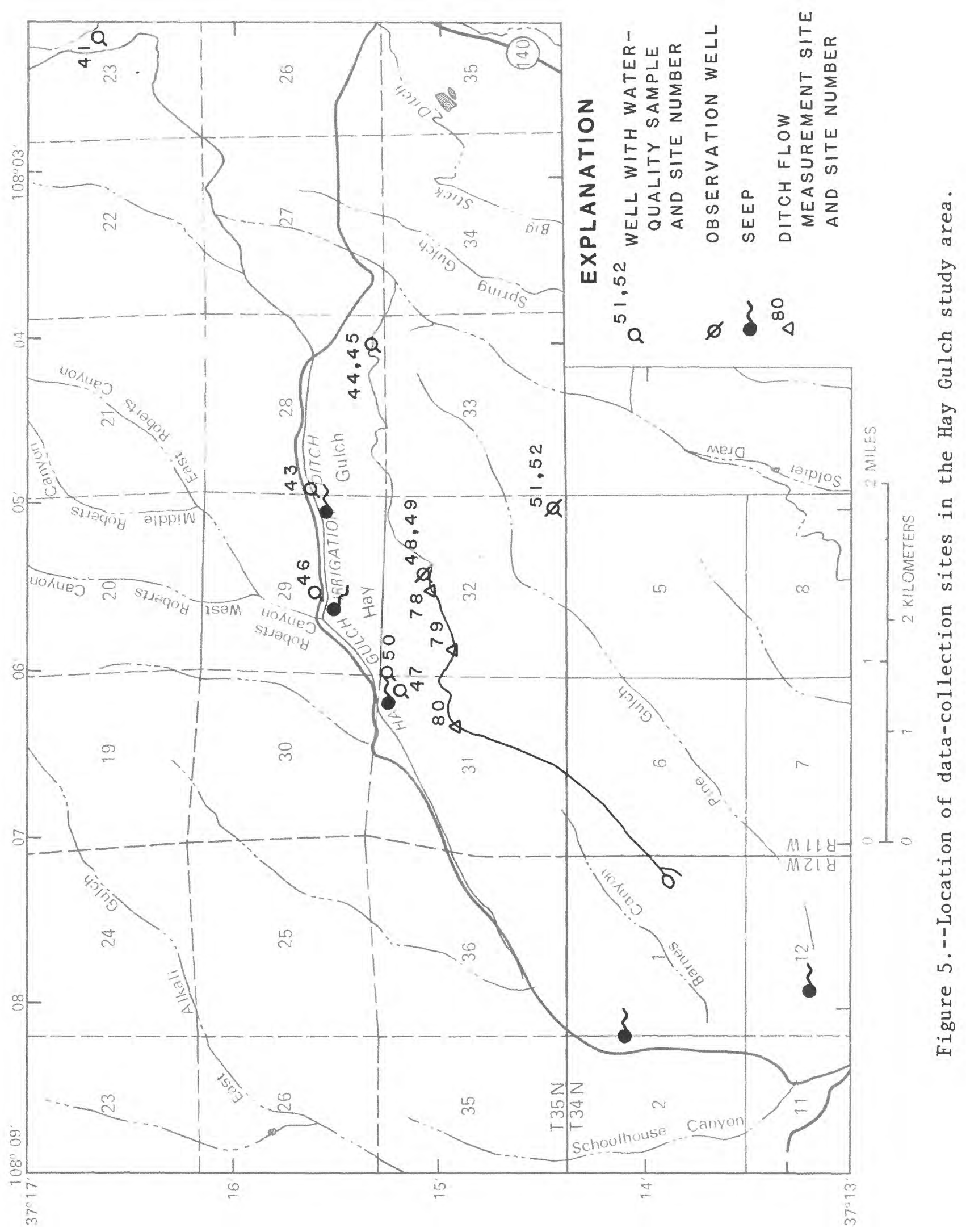




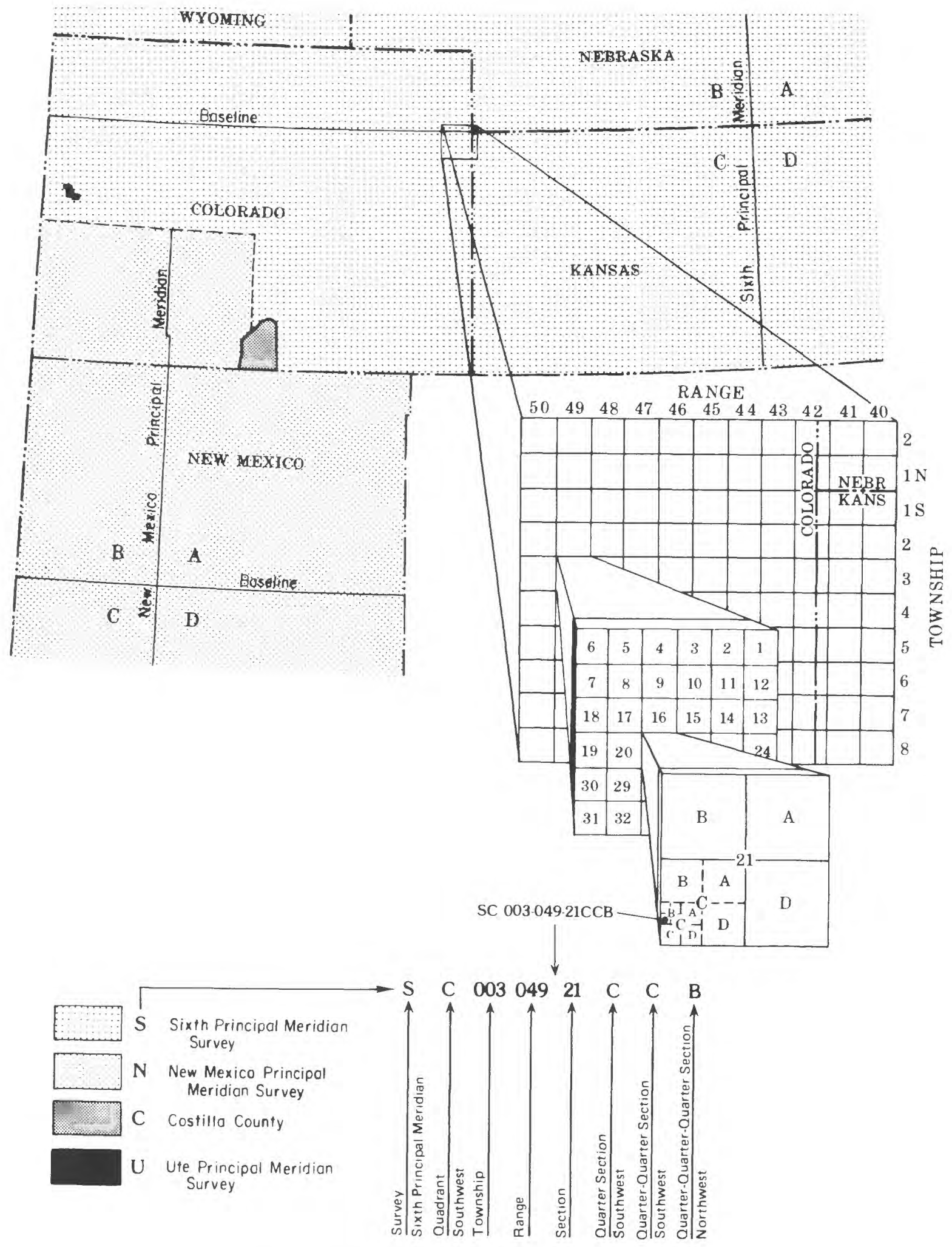

Figure 6.--System of numbering wells, springs, and streamflowmeasurement sites using township, range, and section. 


\section{Acknowledgments}

Property owners allowed access to their lands for data collection. Information supplied by Perma Mining Corporation and National King Coal, Inc. supplemented descriptions of the geology and hydrology near their mines.

\section{GEOLOGY}

\section{Stratigraphy and Lithology}

The stratigraphic units in the Durango study area consist of bedrock and unconsolidated rocks (fig. 7). The geologic units described in this report include (from oldest to most recent) the Mancos Shale, Point Lookout Sandstone, Menefee Formation, Cliff House Sandstone, Lewis Shale, Pictured Cliffs Sandstone, Fruitland Formation, and Kirtland Shale of Late Cretaceous age; Animas and San Jose Formations of Tertiary age; and terrace deposits and alluvium of Quaternary age. Lithologies of bedrock rock include shale, fineto medium-grained sandstone, coal, siltstone, and claystone. Valley-fill alluvium consists of gravel, sand, silt, and clay. Terrace deposits consisting of well-rounded boulders and gravel overlie bedrock. The geologic and lithologic descriptions of geologic units are from Zapp (1949) unless otherwise noted.

The Mancos Shale is a marine shale and approximately 1,900 ft thick near the Animas River. Outcrops are present northeast and northwest of Durango.

The Point Lookout Sandstone typically is a marine, cliff-forming, medium-grained massive sandstone. It is about $400 \mathrm{ft}$ thick in the Durango area and thins eastward. The lower section is transitional and conformable with the underlying Mancos Shale. The lower section of the Point Lookout Sandstone consists of thin sandstone beds with interbedded shale that becomes proportionally thicker in the unit as the formation thins eastward. The upper massive sandstone section is about $100 \mathrm{ft}$ thick at the western boundary of the Durango study area, $70 \mathrm{ft}$ thick near the Animas River, and about $35 \mathrm{ft}$ thick in the Florida River Valley. Outcrop areas are discontinuous in the Durango study area. Some outcrops are about $5 \mathrm{mi}$ west of Durango; some outcrops are northeast of Durango. The Point Lookout Sandstone is the lowest formation of the Mesaverde Group. It is mapped as part of the Mesaverde Group northeast of Durango, near the northern rim of the Durango study area.

The Menefee Formation conformably overlies the Point Lookout Sandstone. Its lithology consists of nonmarine sandstone, shale, and coal. Near the western boundary of the Durango study area, the formation is approximately 350 $\mathrm{ft}$ thick. The formation thins northeastward to approximately $120 \mathrm{ft}$ thick about $10 \mathrm{mi}$ northeast of Durango. Coal is mined from this formation in the Hay Gulch area, but the formation thins abruptly from Hay Gulch east to the La Plata River, a distance less than $5 \mathrm{mi}$. The Menefee Formation is the middle formation of the Mesaverde Group. It is mapped as part of the Mesaverde Group northeast of Durango, near the northern boundary of the Durango study area. 


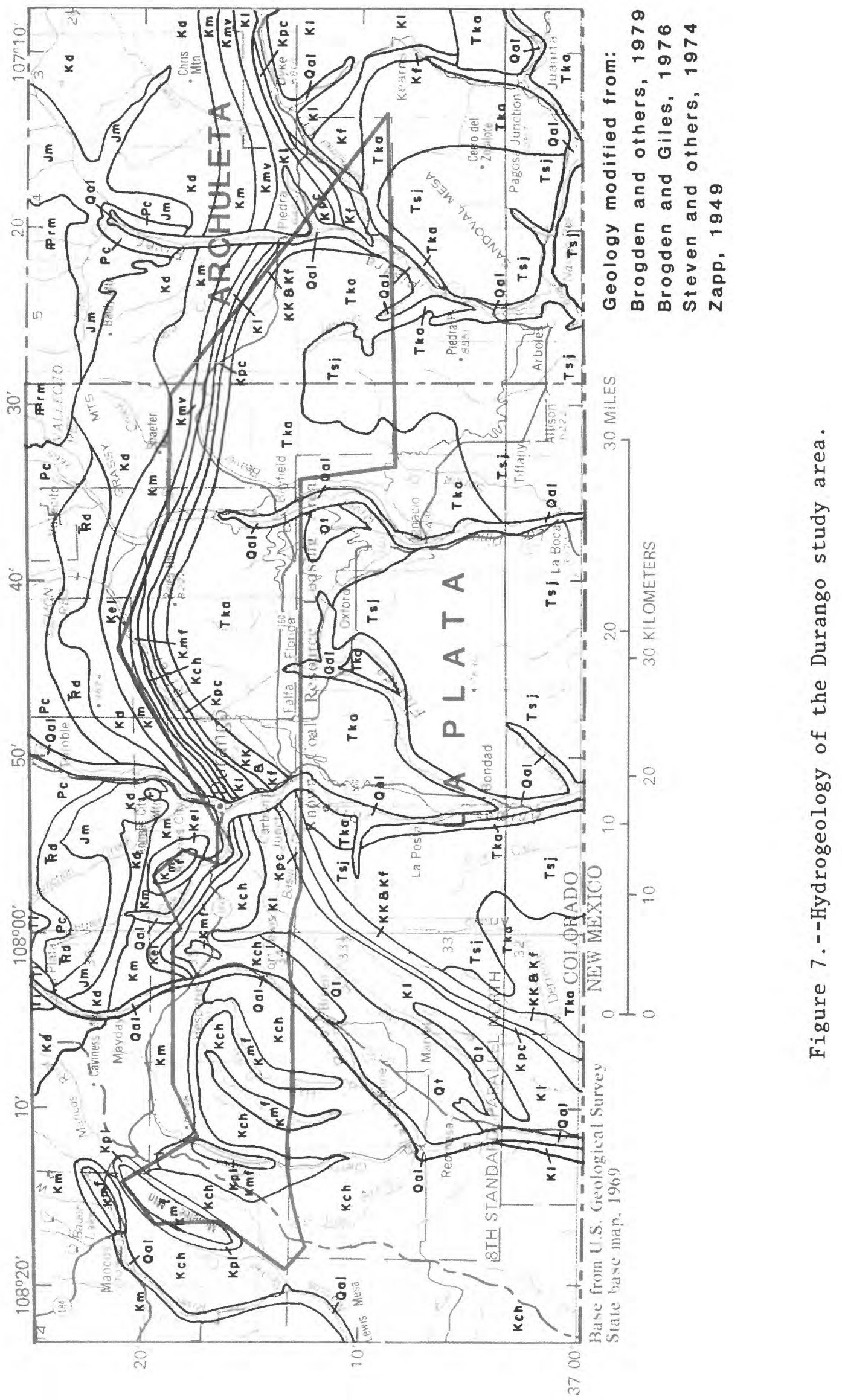




\begin{tabular}{|c|c|c|c|c|c|c|c|c|c|}
\hline 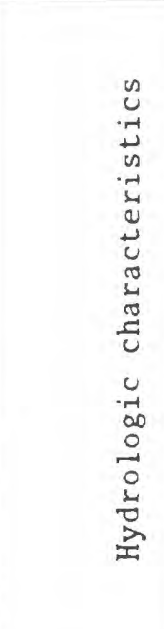 & 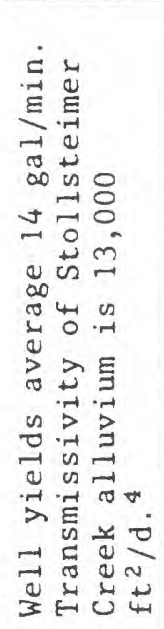 & 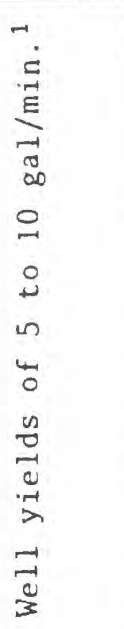 & 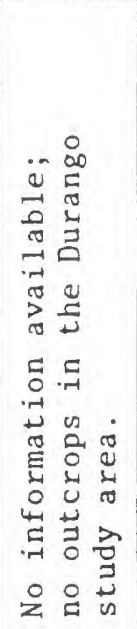 & 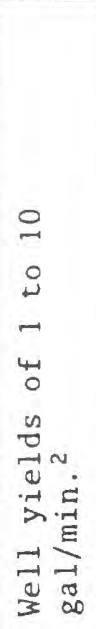 & 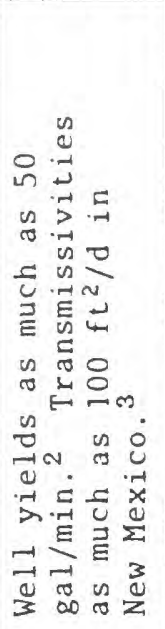 & 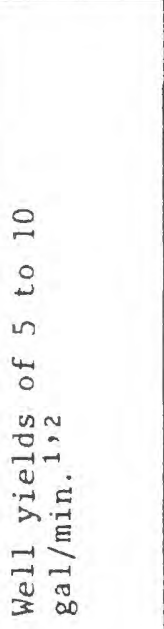 & 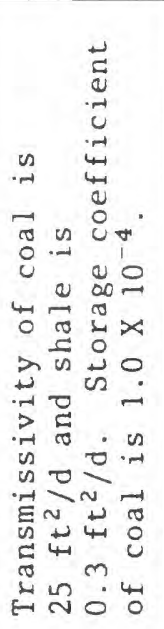 & 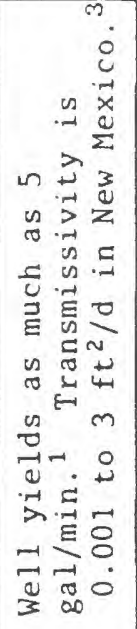 & 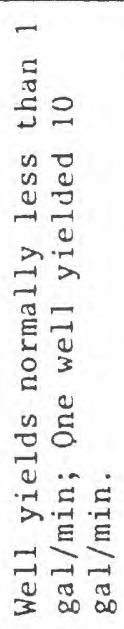 \\
\hline 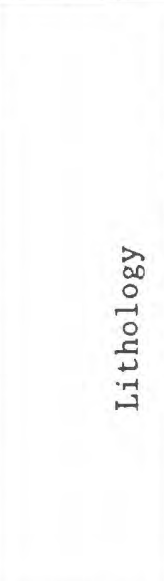 & 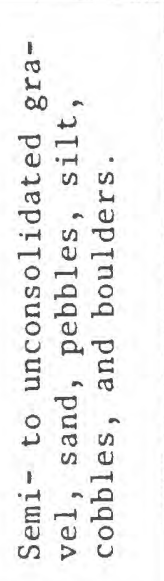 & 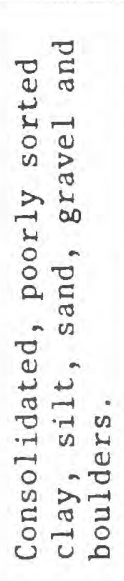 & 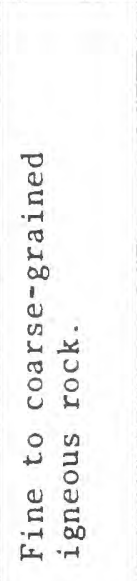 & 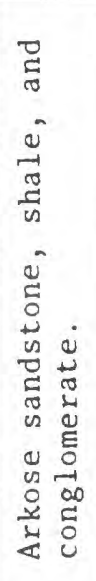 & 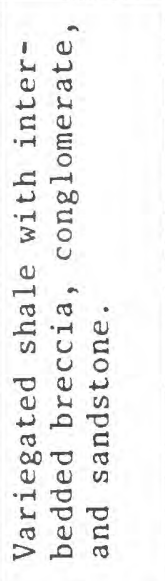 & 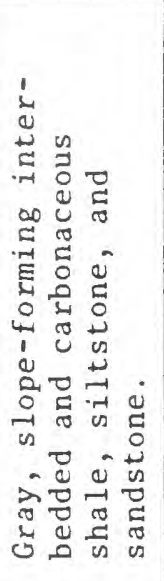 & 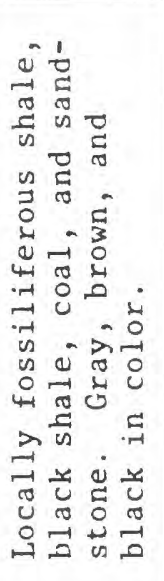 & 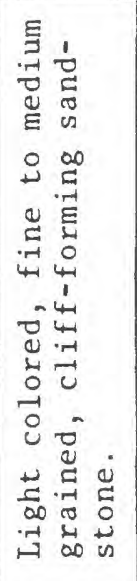 & 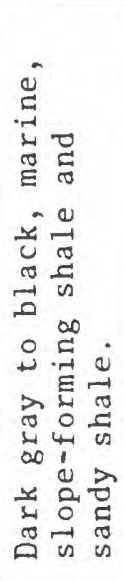 \\
\hline 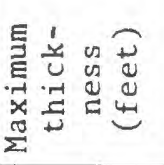 & $\infty$ & $\infty$ & 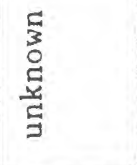 & $\begin{array}{l}8 \\
\text { in } \\
\text { i }\end{array}$ & $\begin{array}{l}\text { O } \\
\text { I } \\
\text { - }\end{array}$ & $\begin{array}{l}\stackrel{\text { I }}{\text { N }} \\
=\end{array}$ & : & : & $\begin{array}{l}\text { N } \\
\infty \\
- \\
-\end{array}$ \\
\hline 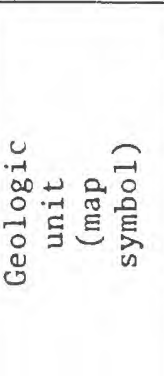 & 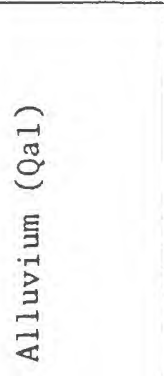 & $\begin{array}{l}0 \\
0 \\
0 \\
0 \\
0 \\
0 \\
0 \\
0 \\
0 \\
0 \\
0 \\
0 \\
0 \\
0 \\
0 \\
0 \\
0\end{array}$ & 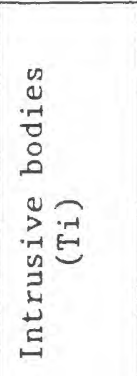 & 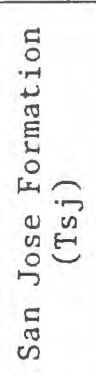 & 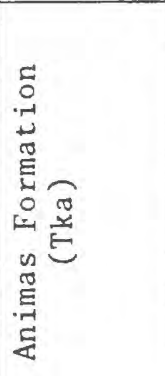 & 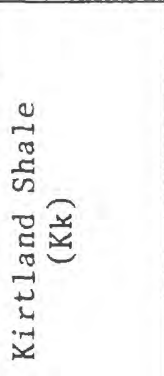 & 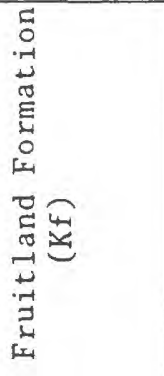 & 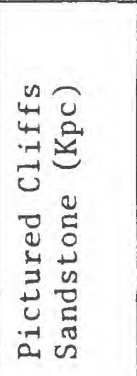 & 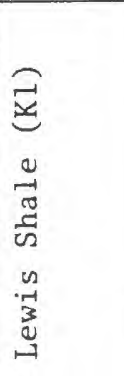 \\
\hline 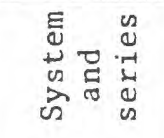 & \multicolumn{2}{|c|}{ ХタษNYGLUกD } & \multicolumn{3}{|c|}{ 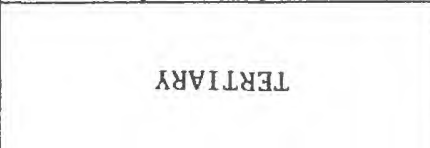 } & \multicolumn{4}{|c|}{ 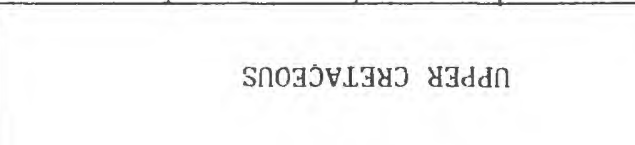 } \\
\hline 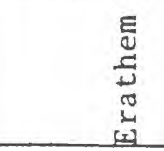 & \multicolumn{5}{|c|}{ วIOZONGJ } & \multicolumn{4}{|c|}{ JIOZOSJW } \\
\hline
\end{tabular}

Figure 7.--Hydrogeology of the Durango study area--Continued. 


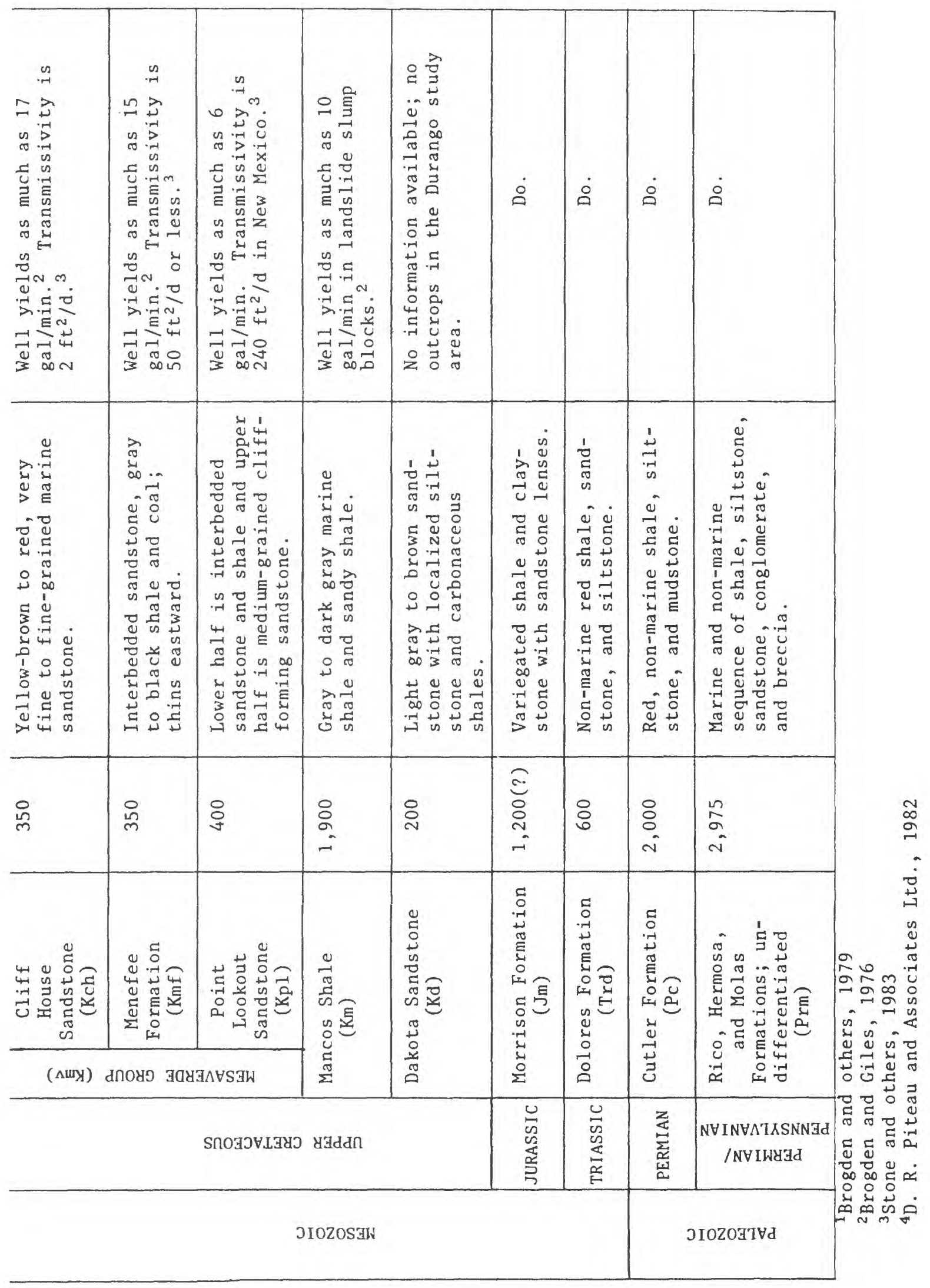

Figure 7.--Hydrogeology of the Durango study area--Continued. 
The Cliff House Sandstone is unconformable or intertongues with the underlying Menefee Formation. It is a very fine- to fine-grained coastal marine sandstone, $325 \mathrm{ft}$ thick in the Durango area. The unit thins and grain sizes are progressively smaller eastward. Outcrops are present west and northeast of Durango. The Cliff House Sandstone is the upper formation of the Mesaverde Group. It is mapped as part of the Mesaverde Group along the northern boundary of the Durango study area east of Durango.

The base of the Lewis Shale intertongues with and conformably overlies the Cliff House Sandstone. It is of marine origin and contains interbedded shale. It is approximately 1,800 ft thick near the Animas River and thickens eastward. The upper $300 \mathrm{ft}$ is sandy and is transitional with the overlying Pictured Cliffs Sandstone. Outcrops are present southwest of Durango and along the northern rim of the Durango study area east of Durango.

The Pictured Cliffs Sandstone is transitional from sandstone to shale, downward through approximately $300 \mathrm{ft}$. It conformably overlies the Lewis Shale. The formation is of marine origin and typically consists of a cliffforming, fine- to medium-grained sandstone. Outcrops are present south of Durango and along the northern boundary of the Durango study area east of Durango. There is a small outcrop in the extreme eastern part of the study area.

The Fruitland Formation and the Kirtland Shale commonly are mapped together and have similar characteristics. The Fruitland Formation is mapped separately in the extreme eastern part of the Durango study area because mining has made available additional geological information. The Fruitland Formation conformably overlies the Pictured Cliffs Sandstone. The Fruitland Formation and the Kirtland Shale consist of shale, sandstone, and coal. Approximate thicknesses are 1,200 ft for the Kirtland Shale and $300 \mathrm{ft}$ for the Fruitland Formation. Outcrops are present south of Durango and in the eastern part of the study area.

The Animas Formation unconformably overlies the undifferentiated Fruitland Formation and the Kirtland Shale. It ranges from unweathered conglomerate to shale with a maximum thickness of $1,400 \mathrm{ft}$. Outcrop areas are extensive in the Durango study area east of Durango.

The San Jose Formation unconformably overlies the Animas Formation. consists of interbedded sandstone, shale, and conglomerate; outcrops are present in the southeastern part of the Durango study area.

Quaternary deposits range from a few feet to $100 \mathrm{ft}$ in thickness and consist of alluvium, colluvium, and terrace deposits. Alluvium in the Durango study area consists of gravel, sand, silt, and various combinations of these materials. Colluvium consists of unsorted gravel, sand, and silt and overlies bedrock. Terrace deposits consist of well-rounded boulders overlying bedrock.

\section{Structure}

The primary structural feature of the Durango study area is the San Juan Basin, which includes parts of New Mexico, Colorado, and Arizona. The Durango 
study area is on the northern rim of the basin (see fig. 1). Stratigraphic units dip toward the basin's center in northwestern New Mexico. In the western part of the Durango study area, the stratigraphic beds dip southeast; in the eastern part of the Durango study area, stratigraphic beds dip southwest. The southward structural dip generally is steepest along the upper rim of the San Juan Basin east of Durango and north of Bayfield where the dip is as much as $55^{\circ}$. The general dip typically is less than $10^{\circ}$.

Secondary structural features in the Durango study area include anticlines, synclines, monoclines, and local faults and fractures. In the central part of the study area are northeastward-trending normal faults with displacements from $60 \mathrm{ft}$ to $300 \mathrm{ft}$. Faults have not been mapped in the specific study areas, although small faults have been encountered during coal mining in the National King Coal Mine in the Hay Gulch study area and in the Chimney Rock Coal Mine in the Stollsteimer Creek study area. Fracturing is common in coal beds in the Fruitland and Menefee Formations.

\section{HYDROGEOLOGY AND GROUND-WATER QUALITY}

\section{Bedrock Units}

The hydrogeologic properties of the bedrock units are dependent primarily on permeability and porosity. Permeability is dependent on interconnected pores, solution channels, and fractures. Other factors that determine hydrologic characteristics are saturated thickness and the continuity of permeable zones. Hydrogeologic characteristics of geologic units in the Durango area and upper San Juan Basin are summarized in the explanation of figure 7.

Transmissivity is a measure of the ability of an aquifer to transmit water. The most transmissive bedrock aquifers in the Durango study area are the Animas Formation and the lower Menefee Formation. Coal seams in the Menefee and Fruitland Formations typically are more permeable than shale or sandstone because of fractures which formed in coal during diagenesis (coal formation). These aquifers yield $10 \mathrm{gal} / \mathrm{min}$ or more, dependent on local hydrologic conditions and well construction. Zapp (1949) reported that the rock units in the Durango study area thin from west to east, probably because of compaction of finer-grained sediment present in the east. Therefore, aquifers also thin eastward and have lower permeability and transmissivity values in the east compared to the west. Other hydrogeologic units in the Durango study area can provide sufficient water for domestic use, although information is insufficient to establish whether or not they contain significant aquifers.

Analyses of water samples indicate that the bedrock aquifers contain water with similar chemical characteristics, except for the Menefee Formation, which contains water with larger dissolved-solids concentrations than other bedrock aquifers. The average concentration of dissolved solids in water in bedrock aquifers is $788 \mathrm{mg} / \mathrm{L}$; values ranged from $135 \mathrm{mg} / \mathrm{L}$ to $3,350 \mathrm{mg} / \mathrm{L}$ (see table 1 in the Supplemental Data section at the back of this report). The principal cations are calcium and magnesium; the principal anions are bicarbonate (alkalinity in table 1) and sulfate. 
The Mancos Shale generally is not considered to be an aquifer through most of its thickness. However, this formation yields water to wells near landslides or in slump blocks, where yields as large as $10 \mathrm{gal} / \mathrm{min}$ are reported (Brogden and Giles, 1976).

The Point Lookout Sandstone potentially is a high-yielding aquifer in the Durango study area, although little hydrologic information is available because the aquifer has been only sparsely developed. This aquifer yields adequate water supplies for domestic use. Well yields of $6 \mathrm{gal} / \mathrm{min}$ have been reported, although greater values can be expected with properly designed and constructed wells. The Point Lookout Sandstone thins eastward, so potential well yields probably decrease toward the east.

Samples were collected from three wells completed in the Point Lookout Sandstone in the Durango study area. No dominant ions were discerned. Dissolved-solids concentrations were $555 \mathrm{mg} / \mathrm{L}, 800 \mathrm{mg} / \mathrm{L}$, and $923 \mathrm{mg} / \mathrm{L}$.

The lower part of the Menefee Formation is more permeable than the upper part and is hydrogeologically connected with the underlying Point Lookout Sandstone. The coal seams are the most permeable zones in the formation because of fractures. Well yields range from $3 \mathrm{gal} / \mathrm{min}$ to $15 \mathrm{gal} / \mathrm{min}$; approximately $8 \mathrm{gal} / \mathrm{min}$ is common. The maximum transmissivity for this formation is expected to be as much as $50 \mathrm{ft}^{2} / \mathrm{d}$ in New Mexico in the San Juan Basin (Stone and others, 1983). The Menefee Formation thins eastward, and a corresponding reduction in transmissivity is likely.

Water samples were collected from 14 wells completed in the Menefee Formation. The dominant ions were sodium and bicarbonate. The ions are distinct compared with ion variations in other samples from other aquifers. Dissolved-solids concentrations ranged from $209 \mathrm{mg} / \mathrm{L}$ to $3,350 \mathrm{mg} / \mathrm{L}$, with an average of $1,090 \mathrm{mg} / \mathrm{L}$.

Wells completed in the Cliff House Sandstone produce as much as 17 $\mathrm{gal} / \mathrm{min}$ in the Durango study area; yields of about $10 \mathrm{gal} / \mathrm{min}$ are common. Permeability probably is greater in the western part of the study area compared to the east because the formation is thicker and contains coarser material. Transmissivity was reported to be $2 \mathrm{ft}^{2} / \mathrm{d}$ in New Mexico in the San Juan Basin (Stone and others, 1983).

Water samples were collected from five wells completed in the Cliff House Sandstone in the Durango study area. The water quality was variable, with no dominant cation and bicarbonate as the dominant anion. Dissolvedsolids concentrations ranged from $135 \mathrm{mg} / \mathrm{L}$ to $1,140 \mathrm{mg} / \mathrm{L}$, with an average of $550 \mathrm{mg} / \mathrm{L}$.

The Lewis Shale is rarely developed for a water supply. One well completed in shale and sandstone beds of the formation had a reported yield of 10 gal/min. Well yields as large as $3 \mathrm{gal} / \mathrm{min}$ are reported south of the Durango study area on the Southern Ute Indian Reservation (Brogden and others, 1979). Much of the Lewis Shale is not an aquifer, based on formation lithology.

No hydrologic information is available for the Pictured Cliffs Sandstone in the Durango study area. Well yields as large as $5 \mathrm{gal} / \mathrm{min}$ are reported 
south of the Durango study area on the Southern Ute Indian Reservation (Brogden and others, 1979). Transmissivity values from $0.001 \mathrm{ft}^{2} / \mathrm{d}$ to $3 \mathrm{ft}^{2} / \mathrm{d}$ were reported in New Mexico within the San Juan Basin (Stone and others, 1983). This formation is not considered to be an aquifer in the Durango study area, based on formation lithology.

The Fruitland Formation and the Kirtland Shale have common lithologic characteristics. Most available hydrologic data are for the Fruitland Formation. Two aquifer tests were performed using a pumping well and an observation well, both completed in the Fruitland Formation near the Chimney Rock Mine in the Stollsteimer Creek study area. These wells have perforations through three coal seams, and shale separates the coal seams. The first test was performed by D.R. Piteau and Associates Limited (1982). This test was a 24-hour drawdown-and-recovery test at a constant discharge. The transmissivity value was $28 \mathrm{ft}^{2} / \mathrm{d}$; the storage coefficient value was $1.3 \times 10^{-4}$. A second test was performed by the U.S. Geological Survey in 1983 using the same wells. The test time was increased to 33 hours, with an average pumping rate of $3.6 \mathrm{gal} / \mathrm{min}$. The transmissivity value was $25 \mathrm{ft}^{2} / \mathrm{d}$, and the storage coefficient was estimated to be $1 \times 10^{-4}$.

Slug tests were performed using two wells near the Chimney Rock Mine. The estimated transmissivity value for a sandstone and shale underlying the lowest coal seam in the Fruitland Formation was $0.3 \mathrm{ft}^{2} / \mathrm{d}$. The estimated transmissivity value for the lower Fruitland Formation and valley colluvium was $125 \mathrm{ft}^{2} / \mathrm{d}$; most of the transmissivity value is due to the greater permeability of the colluvium.

Water samples were collected from six wells completed in the Fruitland Formation in the Stollsteimer Creek study area. One sample was collected from a well completed in the Kirtland Shale. For samples from both formations, the dominant ions were calcium and bicarbonate. Dissolved-solids concentrations ranged from $312 \mathrm{mg} / \mathrm{L}$ to $1,040 \mathrm{mg} / \mathrm{L}$, with an average of $524 \mathrm{mg} / \mathrm{L}$.

The Animas Formation has the best potential of the bedrock units for ground-water development. Wells completed in this formation reportedly yield as much as $50 \mathrm{gal} / \mathrm{min}$ in the Durango study area (Brogden and Giles, 1976), and as much as $75 \mathrm{gal} / \mathrm{min}$ on the Southern Ute Indian Reservation (Brogden and others, 1979), south of the Durango study area. Transmissivity is expected to be $100 \mathrm{ft}^{2} / \mathrm{d}$ in New Mexico in the San Juan Basin (Stone and others, 1983).

Water quality of the Animas Formation is described by Brogden and Giles (1976). The dissolved-solids concentrations ranged from $309 \mathrm{mg} / \mathrm{L}$ to $455 \mathrm{mg} / \mathrm{L}$ for samples from seven wells completed in the Animas Formation.

Little information exists on the San Jose Formation and its ability to transmit ground water in the Durango study area. However, transmissivity of the San Jose Formation may be greater than other bedrock formations, based on formation lithology and aquifer testing south of the Durango study area in New Mexico (Stone and others, 1983). 


\section{Unconsolidated Deposits}

Alluvium deposits contain the best aquifers in the Durango study area, as well as in the San Juan Basin. These aquifers typically yield the most water to wells and contain water of better quality than bedrock aquifers. Well yields were reported to be as much as $500 \mathrm{gal} / \mathrm{min}$ for La Plata River gravels (John Hanau, Amax Coal Company, written commun., 1983). Wells completed in alluvium and colluvium commonly yield from $5 \mathrm{gal} / \mathrm{min}$ to $20 \mathrm{gal} / \mathrm{min}$.

An aquifer test of alluvium along Stollsteimer Creek in the Chimney Rock Mine was performed by D.R. Piteau and Associates Limited (1982). The step-drawdown test determined a transmissivity value of approximately 13,000 $\mathrm{ft}^{2} / \mathrm{d}$.

Water quality in unconsolidated deposits is diverse and commonly is similar to water chemistry of local bedrock. Dominant cations generally were calcium and magnesium; dominant anions generally were bicarbonate and sulfate. Dissolved-solids concentrations ranged from $280 \mathrm{mg} / \mathrm{L}$ to $1,130 \mathrm{mg} / \mathrm{L}$, with an average of $644 \mathrm{mg} / \mathrm{L}$.

\section{STOLLSTEIMER CREEK STUDY AREA}

\section{Location}

The Stollsteimer Creek study area is in the southeast part of the Durango study area (fig. 1) and contains the Chimney Rock Mine tracts (fig. 8). The hydrology of this study area is described as it relates to potential mining impacts.

\section{Surface-Water Characteristics}

The Stollsteimer Creek drainage area, upstream from the confluence with the Piedra River, is $126 \mathrm{mi}^{2}$. Spring runoff usually occurs in April. The average stream slope from Capote Lake to the confluence with the Piedra River is 0.006 , and in the Stollsteimer Creek study area the slope is about 0.007 . The saturated alluvium in the Stollsteimer Creek valley produces perennial flow in Stollsteimer Creek. Maximum stream discharge for Stollsteimer Creek measured near the Chimney Rock Mine (site number 63 in fig. 4) in 1983 was 309 $\mathrm{ft}^{3} / \mathrm{s}$ on April 22; minimum discharge measured at the same location in the same year was $1.84 \mathrm{ft}^{3} / \mathrm{s}$ on October 19 .

Cabezon Creek in Cabezon Canyon (fig. 4) has a drainage area of $6.9 \mathrm{mi}^{2}$, and a stream length of $5.5 \mathrm{mi}$. The stream slope is 0.036 in its main channel. The stream is perennial except during freezing periods in midwinter. Discharge measurements in 1983 at site numbers 61 and 62 (fig. 4) ranged from $7.27 \mathrm{ft}^{3} / \mathrm{s}$ on April 22 to $0.18 \mathrm{ft}^{3} / \mathrm{s}$ on November 7 .

Drainages that are tributary to Stollsteimer Creek have thin alluvium deposits and typically do not support perennial flow. Deep Creek in Deep Canyon (fig. 4) has a drainage area of $4.2 \mathrm{mi}^{2}$, with a main channel length of $4.4 \mathrm{mi}$. The channel slope is 0.046 . The largest discharge measurement in 1983 was $6.41 \mathrm{ft}^{3} / \mathrm{s}$ on April 22 at site number 67 (fig. 4). The creek was dry 


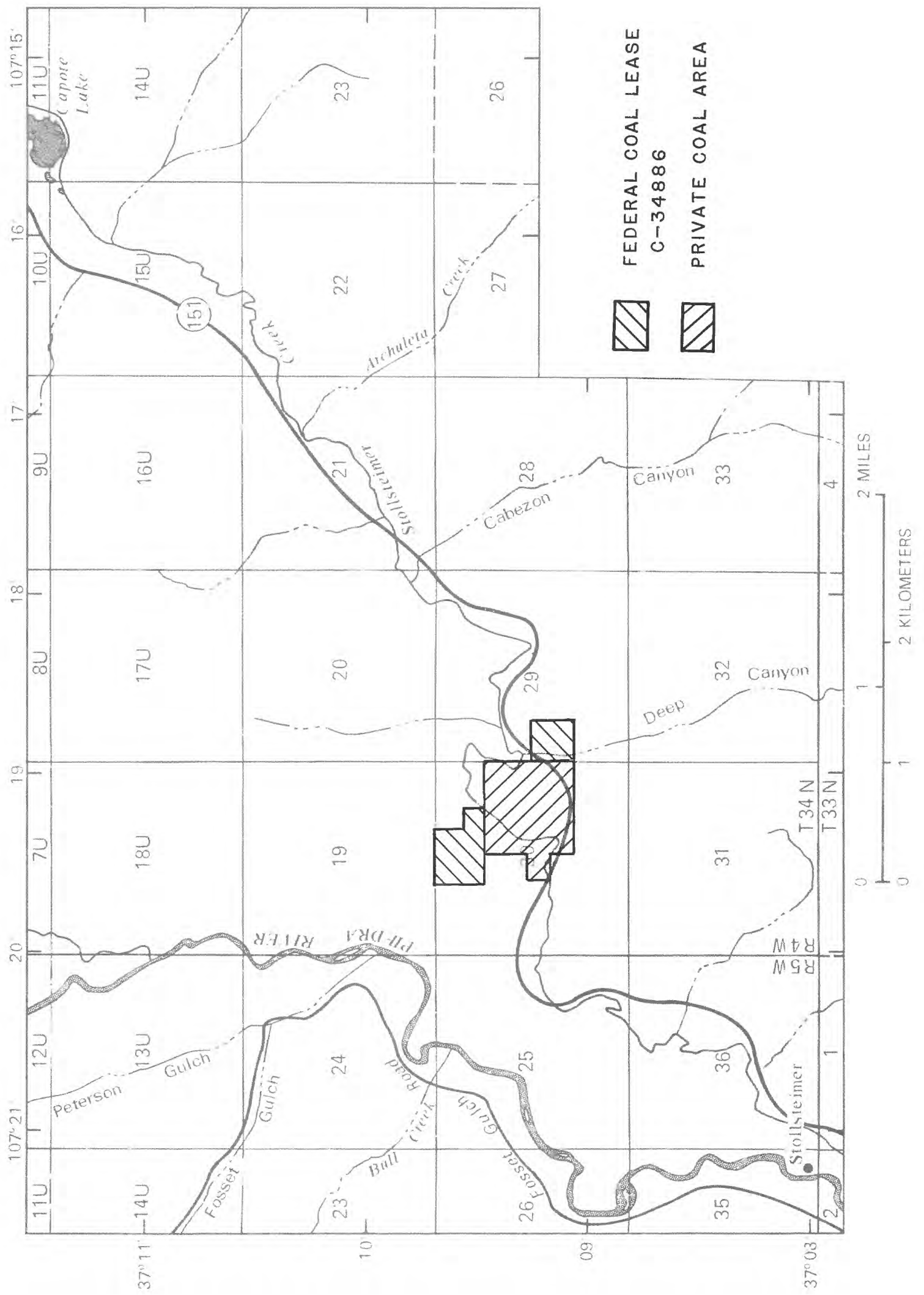

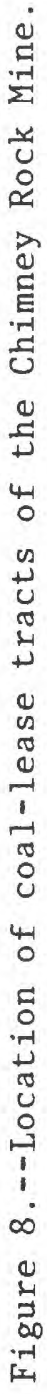


by August 10, 1983. Discharge typically ceases by June or July (as reported by local residents).

Streamflow measurements were used to determine rates of gain or loss on Stollsteimer, Cabezon, and Deep Creeks in 1983. Data for these and other streamflow measurements are in table 4 in the Supplementary Data section at the back of the report.

Stollsteimer Creek gained water between site numbers 64 and 70 (fig. 4) in the mine-lease area in September 1983. Discharge decreased downstream from the mine. In November 1983, Cabezon Creek gained from $0.05 \mathrm{ft} / \mathrm{s}$ to $0.18 \mathrm{ft}^{3} / \mathrm{s}$, between about 1 mile upstream of the confluence with Stollsteimer Creek and near the confluence.

Deep Creek gained from $0.03 \mathrm{ft}^{3} / \mathrm{s}$ to $0.04 \mathrm{ft}^{3} / \mathrm{s}$ between site numbers 65 and 66 when measured in August 1983.

The dominant ions for Stollsteimer, Cabezon, and Deep Creeks were calcium and bicarbonate. Specific-conductance values were larger for water samples taken from Stollsteimer Creek than from its tributaries, probably because of increased traveltime, increased opportunity for dissolution of solids, and increased contribution of ground water from alluvium and bedrock. Specificconductance values increased in the three creeks through summer 1983. Values for creeks sampled on July 21, 1983, were $820 \mu \mathrm{S} / \mathrm{cm}$ (microsiemens per centimeter at $25^{\circ}$ Celsius) for Stollsteimer Creek, $500 \mu \mathrm{S} / \mathrm{cm}$ for Cabezon Creek, and $380 \mu \mathrm{S} / \mathrm{cm}$ for Deep Creek. The nearest sites (site numbers 61, 63, and 67 in fig. 4) were selected for comparison.

\section{Ground-Water Characteristics}

\section{Bedrock Units}

The Pictured Cliffs Sandstone is as much as $250 \mathrm{ft}$ thick in the Stollsteimer Creek study area and dips about $10^{\circ}$ to the southwest. The shale and sandstone in the lower Fruitland Formation likely impede ground-water movement between the Pictured Cliffs Sandstone and overlying formations. No wells are completed in the Pictured Cliffs Sandstone in the Stollsteimer Creek study area or its proximity.

The Fruitland Formation also dips about $10^{\circ}$ to the southwest and is about $100 \mathrm{ft}$ thick at the Chimney Rock Mine. It consists of interbedded sandstone, shale, and coal. Some clay is noted in well drillers' logs.

Three important coal seams in the Fruitland Formation are the A, B, and C seams. The $\mathrm{C}$ seam is the lowest of the three seams. About $30 \mathrm{ft}$ of shale and sandstone separate the $\mathrm{C}$ seam and the Pictured Cliffs Sandstone.

The transmissivity of a 40-ft thickness of the Fruitland Formation, including $A, B$, and $C$ coal seams, was $25 \mathrm{ft}^{2} / \mathrm{d}$; and the storage coefficient was $1.0 \times 10^{-4}$. Slug-type well tests indicated that the Fruitland Formation is less permeable in the zone between the $C$ seam and the underlying Pictured Cliffs Sandstone. The estimated transmissivity value was $0.3 \mathrm{ft}^{2} / \mathrm{d}$. 
The hydraulic gradient in the Fruitland Formation near the mine is toward the Stollsteimer Creek valley. Five wells completed in the Fruitland Formation in the proximity of the Chimney Rock Mine indicate that the aquifer is confined to semiconfined. Four of the wells (site numbers 5, 7, 10, and 18 in fig. 3) are located in the valley floor; the water level in each is above the coal seams. The fifth well (site number 8 in fig. 3) is located north of the mine at a higher altitude. The water level in this well is below the coal seams but higher than the water levels in the other four wells completed in the Fruitland Formation. Therefore, the general direction of ground-water movement is from the well at the north toward the lower four wells. However, little ground water is transmitted because of the small transmissivity of the Fruitland Formation.

Short flow paths predominate in the Fruitland Formation in the Stollsteimer Creek study area. Recharge to the formation occurs from infiltration of precipitation in topographically high areas at surface exposures of the Fruitland Formation or from infiltration through overlying deposits. Discharge occurs to the alluvium in Stollsteimer Creek valley or is lost to evapotranspiration from the Fruitland Formation.

The dominant ions were calcium and bicarbonate in water from the Fruitland Formation in the Stollsteimer Creek study area. Concentrations of dissolved solids ranged from $312 \mathrm{mg} / \mathrm{L}$ to $1,040 \mathrm{mg} / \mathrm{L}$ with an average of 513 $\mathrm{mg} / \mathrm{L}$. Water quality was generally suitable for domestic use, although concentrations of sulfate, iron, and manganese for 13 ground-water and 3 surfacewater samples exceeded U.S. Environmental Protection Agency (U.S. EPA) public drinking-water standards (1977a, 1977b).

\section{Alluvium Deposits}

Alluvial deposits that fill the Stollsteimer Creek valley have a maximum thickness of $60 \mathrm{ft}$ (D.R. Piteau and Associates Limited, 1982). These deposits include coarse-grained sandstone, gravel, and silt near the contact with underlying bedrock. Figure 9 shows a cross section of the alluvium at the Chimney Rock Mine.

Ground-water discharge through the alluvial aquifer in a downstream direction can be determined using Darcy's Law, which may be expressed as:

$$
Q=K I A \text {, }
$$

where

$Q$ is ground-water discharge;

$K$ is the hydraulic conductivity;

$I$ is the hyraulic gradient; and

$A$ is the cross-sectional area of the aquifer. 


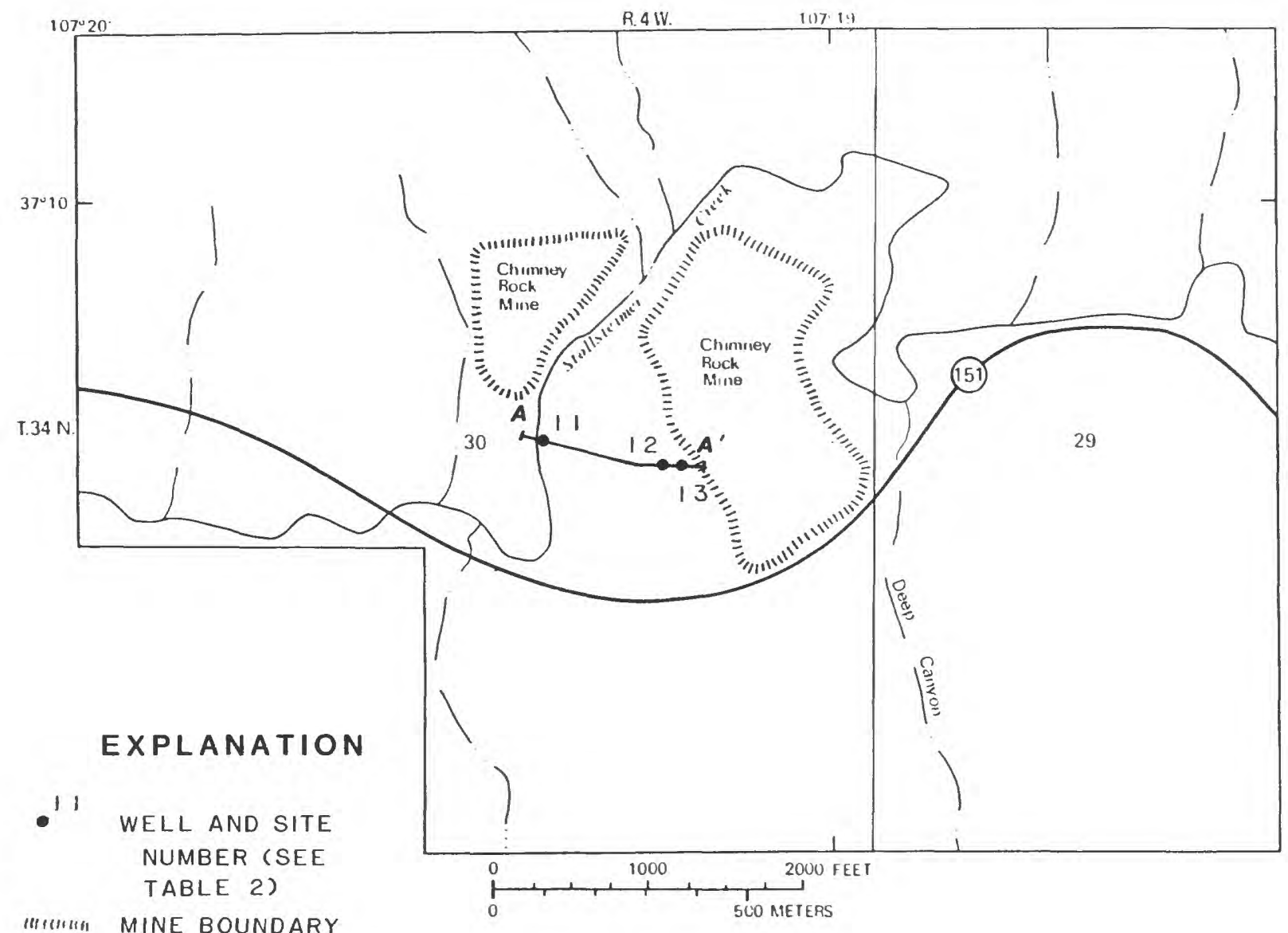

A A' TRACE OF HYDRO -
\[ \text { GEOLOGIC SECTION } \]

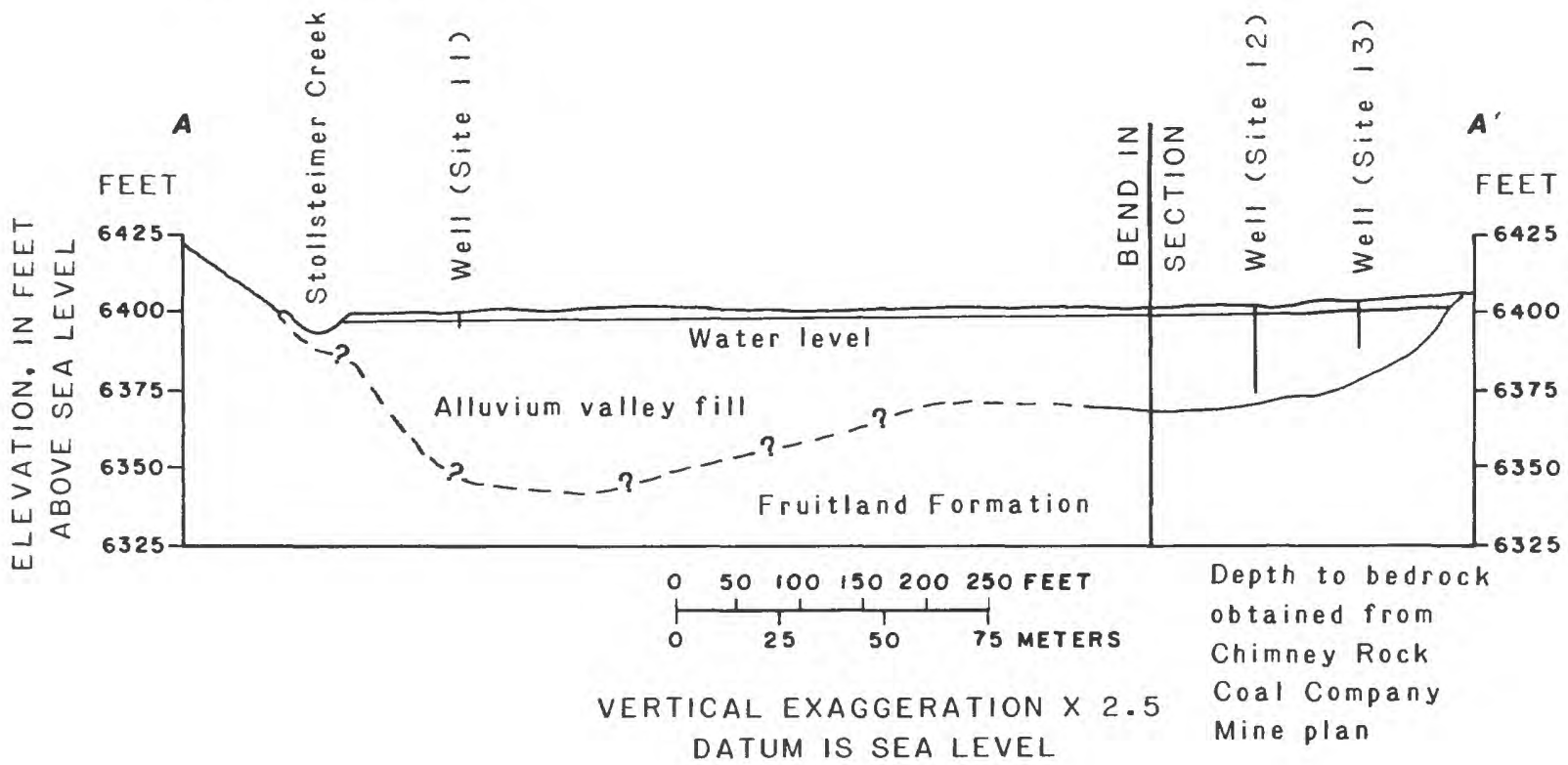

Figure 9.--Map and hydrogeologic section of Stollsteimer Creek valley. 
The transmissivity of a 46-ft thick saturated thickness of the alluvial aquifer is reported to be $13,000 \mathrm{ft}^{2} / \mathrm{d}$ (D.R. Piteau and Associates Limited, 1982); therefore, the average hydraulic conductivity is about $285 \mathrm{ft} / \mathrm{d}$. The hydraulic gradient is assumed to be equal to the stream gradient of 0.007 . The cross-sectional area of saturated alluvium is about $29,000 \mathrm{ft}^{2}$. Therefore, ground-water discharge through the alluvium in a downstream direction is about $0.7 \mathrm{ft}^{3} / \mathrm{s}$, which is about 10 percent of the discharge in Stollsteimer Creek during the summer.

The main source of recharge to the alluvial aquifer in the Stollsteimer Creek study area is from infiltration of precipitation. Lesser amounts of recharge occur by lateral flow from coal beds in the Fruitland Formation. Although some reaches of Stollsteimer Creek may recharge the aquifer, the streamflow measurements made in September 1983 indicate that the alluvium discharges to the creek in the vicinity of the Chimney Rock Mine. Streamflow gains probably result from: (1) A decreased cross-sectional area of the valley alluvium in the vicinity of the mine; (2) discharge to the creek from spoil piles in the mine; and (3) discharge from the Fruitland Formation coal seams that underly the alluvium near the stream-gage site NB03400430ACA (site number 69 in fig. 4). However, the Fruitland Formation contributes relatively little water to streamflow, because the few, thin coal seams transmit little water.

Recharge to Cabezon Creek alluvium is from infiltration of precipitation and from flow through coal beds in the Fruitland Formation where the coal beds are in contact with the alluvium. Discharge from the Fruitland Formation in Cabezon Canyon would raise the specific conductance of the water in the alluvium and increase streamflow in Cabezon Creek. Cabezon Creek gains water downstream from the approximate contact of the Fruitland Formation and alluvium, and these gains coincide with increases in specific-conductance values from $460 \mu \mathrm{S} / \mathrm{cm}$ to $580 \mu \mathrm{S} / \mathrm{cm}$ over about a 1 -mi reach. The specific conductance of a water sample taken from a well (site number 2) completed in the Fruitland Formation in Cabezon Canyon was $698 \mu \mathrm{S} / \mathrm{cm}$.

Deep Canyon has a smaller drainage area than Cabezon Canyon; therefore, there is less opportunity for recharge and discharge. Streamflow in Deep Creek is seasona1 and indicates less ground-water discharge.

Dissolved-solids concentration of an alluvial-water sample from Cabezon Creek (site number 1) was $280 \mathrm{mg} / \mathrm{L}$, and an alluvial-water sample (site number 6) from Deep Creek was $330 \mathrm{mg} / \mathrm{L}$. Dissolved-solids concentration for Stollsteimer Creek alluvium water samples ranged from $330 \mathrm{mg} / \mathrm{L}$ to $1,130 \mathrm{mg} / \mathrm{L}$. Dissolved-solids concentrations are greater for water samples taken from wells completed in Stollsteimer alluvium than for wells completed in Cabezon Canyon and Deep Canyon alluvium. Samples taken from wells completed in Stollsteimer Creek alluvium exceeded the maximum concentration of dissolved solids recommended for public drinking water (U.S. EPA, 1977a). Concentrations of sulfate, iron, and manganese exceeded these standards for 5 out of 7 water samples taken from wells completed in the alluvium along Stollsteimer Creek. 
The dominant ions of water samples taken from wells completed in Stollsteimer Creek alluvium were calcium, sulfate, and bicarbonate. The dominant ions of water samples taken from wells completed in Cabezon Canyon and Deep Canyon alluvium were calcium and bicarbonate. The proportion of bicarbonate anion to sulfate anion is diminished in Stollsteimer Creek alluvium water, compared with Cabezon and Deep Canyon alluvial water.

Water quality in the alluvium is similar to that in the Fruitland Formation. The similarity of water quality, the lack of outcrops of bedrock aquifers upgradient and north of Stollsteimer Creek, and the fact that bedrock of low transmissivity likely discharges any water to adjacent topographic lows suggest that the principal ground-water flow systems are local in the Stollsteimer Creek study area.

\section{Mine Development and Effects}

The Chimney Rock Mine (figs. 8 and 9) ceased mining in July 1985 and is located in the Stollsteimer Creek valley. It was the largest coal mine in the Durango study area and the last active surface mine in the area.

Bedrock overlying the coal was removed from mine pits and backfilled into a previously mined pit, creating spoils. Spoil piles are covered with topsoil and revegetated. In the spring of 1983, spoils were backfilled around a perforated casing in the center of an open pit. This well (site number 15) subsequently has been monitored for depth-to-water and for water quality.

The water table in the spoil pile rose through 1983 and is expected to rise slowly until it reaches equilibrium. The permeability and infiltration rate is much greater for the spoil-pile material than for the original undisturbed bedrock. Vertical hydraulic conductivity is also much greater for spoil-pile material than for bedrock, which allows more infiltration downwards through the pile. A larger volume of ground water is contained in the spoil pile than in a comparable volume of bedrock, and more ground water is transported through the spoils. The permeability of the spoil piles will decrease in time because of weathering of the shale into finer-grained clay and because of spoil-pile compaction.

The principal source of recharge to the spoil piles is from alluvial water upgradient from the spoil piles, based on depth-to-water measurements in wells upstream and downstream from the spoil pile. Alluvial water passes through the spoils material and then returns to the alluvium further down the valley. Recharge from alluvial water will increase the saturated thickness in the spoil pile until the water level is in equilibrium.

Discharge from the spoil pile into Stollsteimer Creek alluvium will increase downstream from the spoils as the water level rises in the spoil pile. Samples from wells completed in alluvium upstream from the spoil piles had an average dissolved-solids concentration of $463 \mathrm{mg} / \mathrm{L}$; samples from wells completed in alluvium downstream from the spoil pile had an average dissolvedsolids concentration of $789 \mathrm{mg} / \mathrm{L}$. The dissolved-solids concentration of water 
in the spoil pile was $559 \mathrm{mg} / \mathrm{L}$. Although the dissolved-solids concentration of water in the spoil pile was greater than the average dissolved-solids concentration of alluvial water upstream, it does not account for the significantly higher values in alluvial waters downstream from the mine. Alluvial water downstream from the spoil piles may be affected by effluent from older spoil piles (more than 10 years) north of the spoil pile from which water was sampled and by the airborn coal dust and mining particulates that have been deposited near the mine.

The dominant ions of the spoil-pile-water sample were sodium and bicarbonate, distinctly different from other ground water sampled in the Stollsteimer Creek study area. Clay and shale zones above and between coal seams are recorded in well-drilling logs and probably are the source of sodium in the spoil pile. The dissolved-solids concentration of ground water in the spoil pile may increase with time because of increasing spoil-pile compaction resulting in the slowing of ground-water movement through the spoil pile.

Chimney Rock Mine had encountered little ground water in recent mining, although dewatering was required in previous pits. Mine workings were above the water table in the Fruitland Formation.

Mining of the Fruitland Formation may cause:

1. Increases of dissolved solids in water in Stollsteimer Creek and alluvium downstream from the mine. These effects would diminish downstream.

2. Temporary dewatering of the Fruitland Formation and adjacent saturated alluvium, if future mining occurs below the water table of the Fruitland Formation.

3. Increased baseflow downstream from the mine because of increased ground-water storage in the spoil piles.

4. Increases in stream sedimentation, dependent on spoil-pile slope stability.

Mining in Deep Canyon or Cabezon Canyon would cause similar effects. Because most ground water in the Stollsteimer Creek study area is within local flow systems, any hydrologic effects from mining in Deep or Cabezon Canyons eventually would affect Stollsteimer Creek and its alluvium.

Increases in dissolved solids would be accompanied by increases in sulfate and sodium concentrations, because greater concentrations of these constituents are found presently in the spoil-pile water. Continued mining is not expected to lower the $\mathrm{pH}$ of Stollsteimer Creek downstream from the mine; the effluent from the spoil piles is small in proportion to the total streamflow in Stollsteimer Creek, and the bicarbonate in the stream and alluvium would buffer any potential changes in the $\mathrm{pH}$ of the stream.

Flooding would increase dissolved solids and sedimentation temporarily in Stollsteimer Creek. A 100-year flood would flush mining contaminants (coal dust and other particulates) from low-lying areas in the mine. The flood 
would have a depth of about $5-\mathrm{ft}$ and a discharge of about $2,000 \mathrm{ft}^{3} / \mathrm{s}$ at the Chimney Rock Mine. These values were calculated using the McCain and Jarrett (1976) method for estimating flood characteristics at ungaged sites. The 100-year flood would cause a backwater reservoix upstream from a culvert (corrugated metal pipe-arch with dimensions of $17.2 \mathrm{ft}$ by $11.3 \mathrm{ft}$ ) located at the northern bend of Stollsteimer Creek separating the two parts of the mine. The headwater altitude at the upstream end of the culvert would be approximately 6,430 ft (using nomagraphs developed by the U.S. Department of Transportation, 1965), and the base of a reclaimed spoil pile near the culvert is about 6,430 ft. The 100-year flood would have little effect on spoil piles.

Reclamation plans state that, at the conclusion of mining, the culvert and associated fill material that dams Stollsteimer Creek will be removed. Therefore, the probability of the culvert being in existence during a 100-year flood event before reclamation would be less than 10 percent.

\section{HAY GULCH STUDY AREA}

\section{Location}

The Hay Gulch study area is in the southwestern part of the Durango study area (fig. 1) and contains the National King Coal Mine tracts (fig. 10). The coal seam being removed at the mine is in the Menefee Formation. The hydrology of this study area is described as it relates to potential mining impacts. The description of upper Hay Gulch in this report refers to the approximate 6-mi reach of Hay Gulch upstream from its confluence with Pine Gulch.

\section{Surface-Water Characteristics}

Surface-water features in the Hay Gulch study area include the Hay Gulch irrigation ditch, the southern diversion of the Hay Gulch irrigation ditch, and upper Pine Gulch. Water flows in the ditches throughout the year. The Hay Gulch irrigation ditch diverts water from the La Plata River near Hesperus (fig. 1) for augmenting streamflow in Hay Gulch. The irrigation diversion also provides water to the lower drainage of Pine Gulch, which is normally dry by early summer. Water is diverted from the Hay Gulch irrigation ditch near the eastern rim of Hay Gulch and into the southern diversion of the Hay Gulch irrigation ditch. The southern diversion runs south of Hay Gulch along the divide between Hay Gulch and Pine Gulch and then enters the lower Pine Gulch drainage above the confluence with Hay Gulch. 


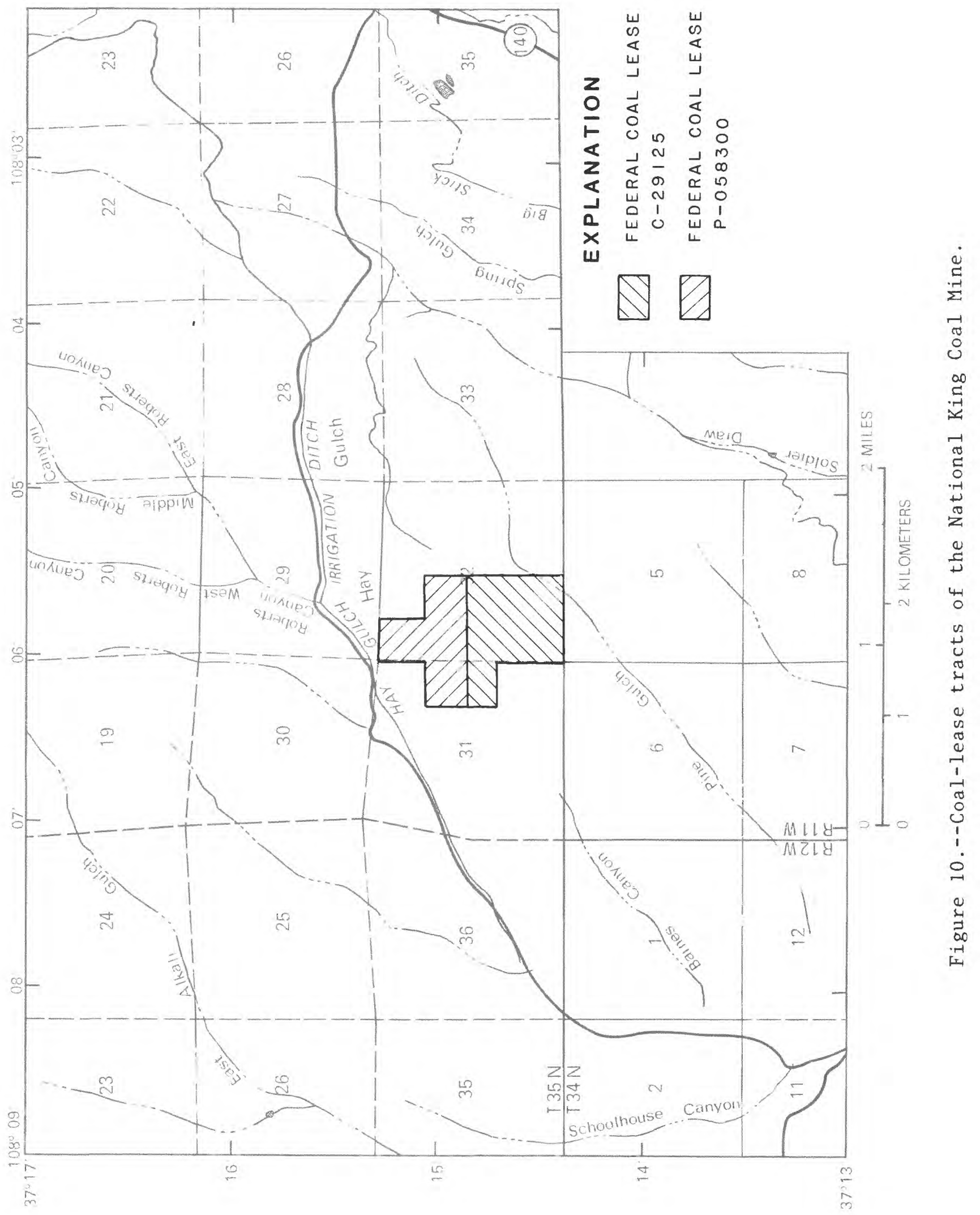


Flow measurements were made on the southern diversion of the Hay Gulch irrigation ditch in July and September 1983. Three flow-measurement sites were selected to determine if fractures from subsidence after mine pillar removal result in a loss of flow. The reach between site number 78 and site number 79 (fig. 5) overlies a part of an underground mine where mine pillars had been removed. The reach between site numbers 79 and 80 overlies a part of an underground mine where mine pillars are still in place. No flow losses were measured in either reach, indicating that there was no leakage from the ditch. However, sediment deposition in the ditch channel probably impedes any infiltration.

The specific conductance of water in the southern diversion of the Hay Gulch irrigation ditch was approximately $150 \mu \mathrm{S} / \mathrm{cm}$, which is similar to the specific conductance of water in the La Plata River from where the water is diverted. The similarity of specific-conductance values indicates no contribution from ground water in the reach from the source at the La Plata River in Hesperus to the flow-measurement sites.

\title{
Ground-Water Characteristics
}

\author{
Bedrock Units
}

Geologic formations in the Hay Gulch study area are the Point Lookout Sandstone, the Menefee Formation, the Cliff House Sandstone, and valley alluvium.

No wells are completed in the Point Lookout Sandstone in the Hay Gulch study area. The formation is recharged through overlying rock and deposits. The Point Lookout Sandstone lithology is transitional with the overlying Menefee Formation.

The Menefee Formation is about $325 \mathrm{ft}$ thick in the Hay Gulch specific study area and dips about $2^{\circ}$ to the southeast. The lower Menefee Formation is saturated and probably is hydrologically connected to the underlying Point Lookout Sandstone. The upper Menefee Formation generally is not considered an aquifer, although underground mining occasionally intercepts and drains small saturated sandstone lenses. The upper Menefee has about seven coal seams. The uppermost coal seam, which is less than $10 \mathrm{ft}$ below the overlying contact with the Cliff House Sandstone, is being removed at the National King Coal Mine.

Three double-completion wells were installed by A.T. Massey Coal Company in 1980 and completed in the Menefee Formation. These wells are located in the Hay Gulch study area, south of Hay Gulch (site numbers 44-45, 48-49, and 51-52). Each double-completion well consists of one well completed in a coal seam in the Menefee Formation and the other well completed in sandstone, less than $40 \mathrm{ft}$ below the coal seam. The interval between completion levels in the hole is sealed with bentonite. The water levels in these wells were used to analyze hydraulic gradients and water movement. The water level of the deeper well was higher than that in the shallow well in two of the three double completions. This suggests that ground water moves upward from the sandstone zone to the more permeable coal units. Data from the the other doublecompletion well are less reliable because of poor well construction. 
Recharge to the Menefee Formation occurs north of the Hay Gulch study area, from precipitation on outcrops or from ground water that infiltrates downward from overlying aquifers. The Menefee Formation also may be recharged by leakage from the overlying alluvial aquifer in Hay Gulch. There is no evidence of major discharge from the Menefee Formation into Hay Gulch. Natural streamflow ceases in upper Hay Gulch by summer.

Ground-water discharge from the Point Lookout Sandstone or Menefee Formation occurs south of the Hay Gulch study area at lower altitudes and may enter the La Plata River drainage. Specific-conductance measurements were made on the La Plata River in February 1984 to determine if the water quality was affected by ground-water discharge into the river. Specific conductance increased from $175 \mu \mathrm{S} / \mathrm{cm}$ near Fort Lewis to $1,430 \mu \mathrm{S} / \mathrm{cm}$ above the confluence with Cherry Creek (fig. 1). The greatest increases were measured between the towns of Breen and Kline and near the confluence with Cherry Creek. Increased specific-conductance values in these reaches may be caused by discharge from the Point Lookout Sandstone and the Menefee Formation, because these are the primary bedrock units in this area. Kline is about 1,000 ft lower in altitude than the potential recharge area in the Hay Gulch study area and about $9 \mathrm{mi}$ south of Hay Gulch.

The dominant ions in the Menefee Formation are distinctly sodium and bicarbonate. Dissolved-solids concentrations for water from the three double-completion wells ranged from $654 \mathrm{mg} / \mathrm{L}$ (site number 44 ) to $1,930 \mathrm{mg} / \mathrm{L}$ (site number 45). These values may indicate longer flow paths within the Menefee Formation, a geohydrologic unit of low-to-fair transmissivity. Small aquifer transmissiviity impedes ground-water movement and increases traveltime, which allows a longer time in contact with solubles in the bedrock. Large concentrations of fluoride and chloride were present in some samples from the Menefee Formation.

The lower Menefee Formation and the Point Lookout Sandstone have better potential for domestic ground-water development than the upper Menefee Formation in the Hay Gulch study area, based on water quality and permeability.

The Cliff House Sandstone overlies the Menefee Formation and is exposed on the divide between upper Hay Gulch and Pine Gulch. In the Hay Gulch study area, the sandstone is about $265 \mathrm{ft}$ thick where it is unweathered and dips about $2^{\circ}$ to the southeast. Water movement from the Cliff House Sandstone into the Menefee Formation probably is not occurring, because the upper Menefee Formation contains little water. Any ground-water movement in the Cliff House Sandstone probably would be horizontal toward the southeast. 


\section{Alluvium Deposits}

The width and thickness of the alluvium are not known. Upper Hay Gulch alluvium is the most permeable aquifer in the Hay Gulch study area. However, alluvial deposits such as in the La Plata River or Stollsteimer Creek drainages are better sorted and, therefore, more permeable.

The alluvium in upper Hay Gulch generally is saturated. Several seep areas are in the valley floor (fig. 5). The seep areas are located near the valley sides and at the confluence of a tributary. The valley floor has more vegetation than the higher divides between drainages. Most of upper Hay Gulch is used for growing hay and for grazing.

One of the six residences in upper Hay Gulch used water from the alluvial aquifer. The other five residences used water from the Hay Gulch irrigation ditch for homes and irrigation, because the alluvial water quality is unsuitable. The dominant cations of alluvial water were calcium and magnesium; the dominant anion was sulfate.

The alluvium in Pine Gulch is shallow and is sufficiently saturated to support grass growth through the summer; pinon-juniper is more typical vegetation at the higher altitudes surrounding Pine Gulch. The saturated alluvium in Pine Gulch is underlain by the lower part of the Cliff House Sandstone.

\section{Mine Development and Effects}

The National King Coal Mine (figs. 10 and 11) will continue to mine southward, using room-and-pillar methods. The southern lease tract underlies part of the upper drainage of Pine Gulch, but an agreement with the U.S. Bureau of Land Management permits mining west from the northwest quarter of the southwest quarter of section 32 (T. $35 \mathrm{~N} ., \mathrm{R} .11 \mathrm{~W}$.$) rather than under-$ mining Pine Gulch. As little as $50 \mathrm{ft}$ of overburden separate Pine Gulch alluvium and the upper coal seam currently mined by National King Coal Mine in the Menefee Formation.

No measurable dewatering of the southern diversion of the Hay Gulch irrigation ditch has occurred. The National King Coal Mine withdraws alluvial water for mine operation, but the pumping does not significantly dewater the aquifer. Mining occurs above the potentiometric surface in the Menefee Formation, so that only small, permeable lenses are dewatered during mining.

Underground mining has caused tension cracks in the Cliff House Sandstone. These cracks occurred through about $300 \mathrm{ft}$ to $400 \mathrm{ft}$ of overburden above the underground mine. Some were visible at land surface (fig. 11). Most cracks were less than $40 \mathrm{ft}$ long and 6 in. wide, although one crack near the sandstone rim above the mine was about $450 \mathrm{ft} 1$ long and up to $1 \mathrm{ft}$ wide. Stresses originate where support pillars adjoin open rooms and when pillars in the mine are collapsed after mining is completed. There is about $350 \mathrm{ft}$ of overburden between the longest surface subsidence crack and the underground mine. The limit angle (the angle, measured from the vertical, between the point of stress in the underground mine and the surface crack) is about $30^{\circ}$, which is typical of limit angles in the Somerset mining district, Colorado 


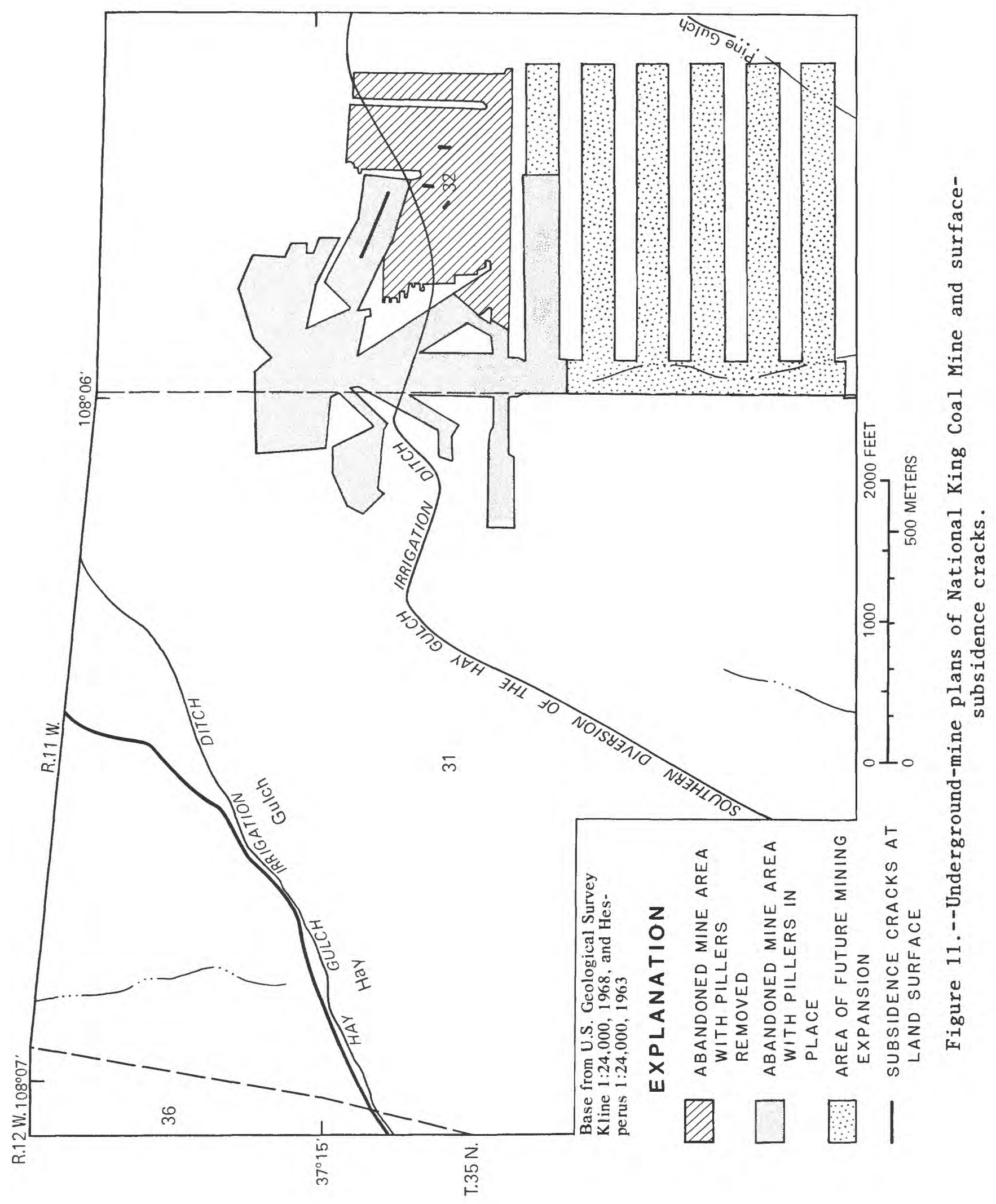


(Dunrud, 1976). Subsidence effects diminish with increased thickness of overburden. Subsidence will continue during underground mining, and new tension cracks likely will appear at land surface.

Three wells in upper Hay Gulch are completed in the alluvium and are useful in describing the possible effects of mining on water quality in upper Hay Gulch. The first well (site number 43 in fig. 5) is about 1 mi upstream from the National King Coal Mine. The second well (site number 50 in fig. 5) is located in the National King Coal Mine. The third well (site number 47 in fig. 5) is located about $600 \mathrm{ft}$ downstream of the National King Coal Mine.

Specific-conductance values were $1,340 \mu \mathrm{S} / \mathrm{cm}$ for a water sample from the upstream well (site number 43 in fig. 5), 4,200 $\mu \mathrm{S} / \mathrm{cm}$ for a water sample taken from the mine well (site number $50 \mathrm{in} \mathrm{fig.} \mathrm{5),} \mathrm{and} \mathrm{2,450} \mathrm{\mu S/cm} \mathrm{for} \mathrm{a} \mathrm{water}$ sample taken from the downstream well (site number 47). Concentrations of calcium, magnesium, sodium, nitrate, sulfate, copper, lead, and nickel were greatest in water from the well in the mine, the next greatest in water from the well downstream from the mine, and the smallest in water from the well upstream from the mine. Field $\mathrm{pH}$ values for the three water samples were 7.3 upstream, 6.7 in the mine, and 7.1 downstream. Ground-water temperatures were $9.5^{\circ} \mathrm{C}$ upstream, $12^{\circ} \mathrm{C}$ in the mine, and $10^{\circ} \mathrm{C}$ downstream.

Surface runoff from mine areas during the spring snowmelt recharge the alluvial aquifer in upper Hay Gulch. About 15 abandoned mines, most of which are small, are located from about $2 \mathrm{mi}$ upstream to $1 \mathrm{mi}$ downstream of the National King Coal Mine. Mining contaminants have degraded alluvial water quality over the past 100 years. The magnitude of the effect on water quality is not possible to measure, because the natural water quality was not evaluated prior to mining.

Most ground water in the Hay Gulch study area moves downvalley through the Hay Gulch alluvium. Water discharged from the alluvium probably recharges the underlying Menefee Formation and Point Lookout Sandstone and flows south and southeast to the La Plata River, or further south. Mining contaminants that enter the bedrock aquifers through the alluvial aquifer would be transmitted to distant drainages, although the rate would be slow and the volume would be small in proportion to total ground-water flow in the region.

\section{NEEDS FOR FUTURE STUDIES}

Additional data collection and analysis are needed in the Durango study area to better describe the hydrogeologic conditions and the potential effects of mining. The interpretation in this report is limited by the number of existing ground-water data-collection sites. Few reports are available that describe the regional hydrology.

The extent of mining impacts on ground water in the Durango study area is dependent on whether flow systems are local, intermediate, or regional. To determine these flow systems, additional streamflow measurements could be made on more streams and rivers to help identify natural discharge from aquifers. 
Open-pit mining in Cabezon or Deep Canyons of the Stollsteimer Creek study area probably will result in dewatering during mining, but it is not certain which aquifers could be affected. Wells designed for water-level monitoring and water-quality monitoring prior to mining would help to describe flow systems in the area. Water in spoil piles, alluvium, streams, and bedrock could be sampled and analyzed during this transition period.

Flow systems in the Hay Gulch area need to be defined more specifically. Mine contaminants could be transported through Hay Gulch valley alluvium and into the underlying Menefee Formation and the Point Lookout Sandstone. Ground water in these aquifers might discharge into the La Plata River and increase metal concentrations downstream.

The hydrologic interpretation of the Hay Gulch study area is based on very little data. Additional wells drilled in the alluvium and in the adjacent bedrock would help determine hydraulic gradients in the Hay Gulch area. New wells could be specifically designed for the collection of hydrologic information. Ground-water information from additional wells also would help to define recharge and discharge relationships. Wells could be designed for aquifer testing that would provide values for transmissivity and storage coefficient for various aquifers.

In conclusion, it is important to monitor changes and to describe the hydrologic systems prior to large-scale mining so that future mining impacts may be assessed.

\section{SUMMARY AND CONCLUSIONS}

\section{$\underline{\text { Hydrology }}$}

The major aquifers in the Durango study area are alluvial aquifers located in stream valleys and the Animas Formation. Water wells completed in alluvium typically yield 5 to 20 gallons per minute. Water quality in these hydrogeologic units is variable but generally suitable for domestic use. The lower part of the Menefee Formation is developed, but the water generally has high concentrations of dissolved solids. Aquifer permeability generally decreases from west to east in the Durango study area. Other formations are poor aquifers, have unsuitable water quality, or have little known about them.

Water in the Menefee Formation and the Point Lookout Sandstone characteristically have large concentrations of dissolved solids that may indicate long flow systems. Most ground-water in the Durango study area is in local flow systems.

The dominant ions for surface water in the Stollsteimer Creek study area were calcium and bicarbonate. Specific-conductance values were less than $1,000 \mu \mathrm{S} / \mathrm{cm}$ and increased downstream. The dominant ions of water samples taken from the coal-bearing Fruitland Formation in the Stollsteimer Creek study area were calcium and bicarbonate. Dissolved-solids concentrations of water from the Fruitland Formation ranged from $312 \mathrm{mg} / \mathrm{L}$ to $1,040 \mathrm{mg} / \mathrm{L}$. There were large concentrations of sulfate, iron, and manganese in some ground-water and surface-water samples. 
The Hay Gulch irrigation ditch and the southern diversion of the Hay Gulch irrigation ditch are the only perennial surface waters in the Hay Gulch study area. The ditches divert water from the La Plata River and had specific conductance values of about $150 \mu \mathrm{S} / \mathrm{cm}$ in September 1983. The dominant ions in the coal-bearing Menefee Formation in the Hay Gulch study area were sodium and bicarbonate. Dissolved-solids concentrations for water samples from wells completed in the Menefee Formation ranged from $654 \mathrm{mg} / \mathrm{L}$ to $1,930 \mathrm{mg} / \mathrm{L}$.

\section{Mining Effects}

Mining of coal in the Fruitland Formation in the Stollsteimer Creek study area probably will result in generally acceptable hydrologic impacts if previous mining methods by Chimney Rock Mine were continued. Surface- and ground-water quality are degraded in the Stollsteimer Creek study area, but quality is expected to remain within acceptable levels. Aquifers in the alluvium and the Fruitland Formation have been dewatered in the Stollsteimer Creek study area. More information is needed to accurately assess potential impacts from spoil piles.

Mining of coal in the Menefee Formation in the Hay Gulch study area has resulted in the degradation of water quality in the alluvial aquifer. Contamination from past and present mining has affected water quality in the alluvium in upper Hay Gulch and, possibly, the lower Menefee Formation and Point Lookout Sandstone aquifers. No surface-water losses have occurred through subsidence cracks caused by underground mining. Mining beneath Pine Gulch probably would result in dewatering of overlying aquifers.

\section{Needs for Future Studies}

Increasing interest in Federal coal leasings in the Durango study area requires a clearer understanding of hydrology in the Durango study area and its relationship with coal deposits. Effects from coal mining may extend to distant drainages. Additional data collection would provide a more complete framework for assessing the hydrologic effects of mining. 


\section{REFERENCES}

Brogden, R.E., Hutchinson, E.C., and Hillier, D.E., 1979, Availability and quality of ground water, Southern Ute Indian Reservation, southwestern Colorado: U.S. Geological Survey Water-Supply Paper 1576-J, $28 \mathrm{p}$.

Brogden, R.E., and Giles, T.F., 1976, Availability and chemical characteristics of ground water in central La Plata County, Colorado: U.S. Geological Survey Water-Resources Investigations Report 76-69, scale $1: 125,000$.

D.R. Piteau and Associates Ltd., 1982, Preliminary aquifer analysis and estimation of groundwater inflow to two open pits, project number D82-301: Lakewood, Colo., unpublished report, $53 \mathrm{p}$.

Dunrud, C.R., 1976, Some engineering geologic factors controlling coal mine subsidence in Utah and Colorado: U.S. Geological Survey Professional Paper $969,39 \mathrm{p}$.

McCain, J.F., and Jarrett, R.D., 1976, Manual for estimating flood characteristics of natural-flow streams in Colorado: Denver, Colorado Water Conservation Boaxd, Technical Manual number 1, $68 \mathrm{p}$.

National Climatic Data Center, 1983, Climatological data, Annual summary, Colorado, Durango station: Asheville, N.C.

Steven, T.A., Lipman, P.W., Hail, W.J., Jx., Barker, Fred, and Luedke, R.G., 1974, Geologic map of the Durango quadrangle, southwestern Colorado: U.S. Geological Survey Miscellaneous Investigations Map I-764, scale 1:250,000.

Stone, W.J., Lyford, F.P., Frenzel, P.F., Mizell, N.H., and Padgett, E.T., 1983, Hydrogeology and water resources of San Juan Basin, New Mexico: Socorro, New Mexico Bureau of Mines and Mineral Resources Hydrologic Report 6, 70 p.

U.S. Department of Transportation, 1965, Hydraulic charts for the selection of highway culverts: Washington, D.C., Federal Highway Administration Hydraulic Engineering Circular no. 5, 54 p.

U.S. Environmental Protection Agency, 1977a, National interim primary drinking water regulations: Washington, D.C., EPA-570/9-76-003, 159 p. $1977 b$, National secondary drinking water regulations (proposed): Federal Register, v. 42, no. 62, Mar. 31, Part I, p. 17143-17147.

Zapp, A.D., 1949, Geology and coal resources of the Durango area, La Plata and Montezuma Counties, Colorado: U.S. Geological Survey Oil and Gas Investigations Map OM-109, scale 1:31,680. 
SUPPLEMENTARY DATA 
Table 1.--Chemical analyses of water samples from wells, springs, and streams

$\left[\mu \mathrm{S} / \mathrm{cm}\right.$, microsiemens per centimeter at $25^{\circ} \mathrm{Celsius;} \mathrm{mg/L,} \mathrm{milligram} \mathrm{per} \mathrm{liter;} \mu \mathrm{g} / \mathrm{L}$, microgram per liter;

$<$, less than; underlined values exceeded primary public drinking water standards; boldface values exceed secondary public drinking water standards, established by the U.S. Environmental Protection Agency (1977a, 1977b)]

\begin{tabular}{|c|c|c|c|c|c|c|c|c|c|c|}
\hline $\begin{array}{l}\text { Site } \\
\text { number } \\
\text { (see } \\
\text { figures } \\
2-5 \text { ) }\end{array}$ & $\begin{array}{c}\text { Local } \\
\text { identifier } \\
\text { (see } \\
\text { figure 6) }\end{array}$ & $\begin{array}{l}\text { Site } \\
\text { type }\end{array}$ & Sample source & $\begin{array}{c}\text { Date } \\
\text { of } \\
\text { sample }\end{array}$ & $\begin{array}{l}\text { Temper- } \\
\text { ature } \\
\text { in } \\
\text { degrees } \\
\text { Celsius }\end{array}$ & $\begin{array}{c}\mathrm{pH} \\
\text { (stand- } \\
\text { ard } \\
\text { units) }\end{array}$ & $\begin{array}{l}\text { Spe- } \\
\text { cific } \\
\text { con- } \\
\text { duct- } \\
\text { ance } \\
(\mu \mathrm{S} / \mathrm{cm})\end{array}$ & $\begin{array}{c}\text { Solids, } \\
\text { sum of } \\
\text { consti- } \\
\text { tuents, } \\
\text { dis- } \\
\text { solved } \\
(\mathrm{mg} / \mathrm{L})\end{array}$ & $\begin{array}{l}\text { Hard- } \\
\text { ness } \\
(\mathrm{mg} / \mathrm{L} \\
\text { as } \\
\left.\mathrm{CaCO}_{3}\right)\end{array}$ & $\begin{array}{l}\text { Potas- } \\
\text { sium, } \\
\text { dis- } \\
\text { solved } \\
\text { (mg/L } \\
\text { as K) }\end{array}$ \\
\hline 1 & NB03400428BDD1 & Well & Alluvium & $83-07-19$ & 14.0 & 6.5 & 575 & 280 & 190 & 2.4 \\
\hline 2 & NB03400428DCD 1 & We 11 & Fruitland Formation & $83-07-27$ & 10.5 & 6.9 & 698 & 446 & 340 & 1.9 \\
\hline 3 & NB03400429ACC1 & Well & Alluvium & $83-08-16$ & 11.0 & 7.2 & 1100 & 678 & 490 & 2.5 \\
\hline 5 & NB03400429CBB1 & We11 & Fruitland Formation & $83-07-15$ & 13.0 & 6.9 & 735 & 400 & 270 & 3.0 \\
\hline 6 & NB03400429CBB2 & We11 & Alluvium & $83-11-08$ & 8.0 & 7.4 & 576 & 330 & 220 & 3.2 \\
\hline 7 & NB03400429CBB3 & Well & Fruitland Formation & $83-11-08$ & 10.0 & 7.2 & 1410 & 1040 & 700 & 6.0 \\
\hline 8 & NB03400430ABB 1 & Well & Fruitland Formation & $83-11-08$ & 12.0 & 7.4 & 836 & 434 & 180 & 7.4 \\
\hline 10 & NB03400430ACC 1 & Well & Fruitland Formation & $83-08-22$ & 13.5 & 6.6 & 790 & 512 & 360 & 2.2 \\
\hline 11 & NB03400430ACD 1 & Well & Alluvium & $83-07-20$ & 18.0 & 5.9 & 1330 & 758 & 650 & 12 \\
\hline 12 & NB03400430ADCl & Well & Alluvium & $83-07-15$ & 12.0 & 7.1 & 898 & 591 & 430 & 2.7 \\
\hline 13 & NB03400430ADC2 & Well & Alluvium & $83-07-15$ & 14.5 & 6.9 & 1330 & 953 & 700 & 4.6 \\
\hline 14 & NB03400430ADD1 & Well & Alluvium & $83-07-19$ & 13.0 & 6.5 & 817 & 565 & 400 & 3.6 \\
\hline 15 & NB03400430DAA1 & Well & Spoil pile & $83-07-27$ & 11.0 & 8.0 & 897 & 559 & 90 & 2.6 \\
\hline 16 & NB03400430DBA1 & Well & Alluvium & $83-07-20$ & 18.0 & 5.9 & 1420 & 1130 & 800 & 7.1 \\
\hline 17 & NB03400430DBB 1 & Well & Alluvium & $83-07-19$ & 16.0 & 6.5 & 798 & 513 & 360 & 3.5 \\
\hline 18 & NB03400430DBB2 & Well & Fruitland Formation & $83-07-22$ & $-\ldots$ & -- & --- & 312 & 210 & 2.1 \\
\hline 24 & $\mathrm{NB} 03401001 \mathrm{CCB}$ & We11 & Cliff House Sandstone & $74-12-12$ & 8.0 & 8.2 & 1600 & 1140 & 18 & 2.0 \\
\hline 25 & NB03401206CDA & We 11 & Menefee Formation & $75-04-10$ & 12.0 & 6.8 & 3440 & 3350 & 2000 & 7.1 \\
\hline 27 & NB0 3500803 CAAl & Well & Cliff House Sandstone & $83-07-29$ & 9.5 & 7.3 & 417 & 255 & 180 & 1.4 \\
\hline 28 & NB03500808CCB1 & Well & Point Lookout Sandstone & $74-12-12$ & 6.0 & 7.1 & 1060 & 800 & 250 & 2.8 \\
\hline 29 & NB03500819BCD & Well & Kirtland Shale & $75-04-15$ & 8.5 & $-\cdots$ & 710 & 444 & 310 & .9 \\
\hline 31 & NB03501028CDA1 & We 11 & Menefee Formation & $83-06-08$ & 9.0 & 7.0 & 1860 & $-\cdots$ & 840 & $\cdots$ \\
\hline 32 & NBO350 $1028 C D A 2$ & We11 & Menefee Formation & $83-06-08$ & 12.0 & 7.8 & 1030 & --- & 200 & --- \\
\hline 33 & NB0350 $1028 \mathrm{DCC} 1$ & Well & Menefee Formation & $83-06-08$ & 14.5 & 8.7 & 1150 & 694 & 2 & 1.1 \\
\hline 34 & NB03501028DDB1 & We11 & Menefee Formation & $83-07-26$ & 15.0 & 8.2 & 1340 & 846 & 14 & 1.4 \\
\hline 35 & NB03501034BBC & We11 & Menefee Formation & $75-04-08$ & 9.0 & 7.7 & 1500 & 1090 & 4 & 2.4 \\
\hline 36 & NB0350 $1034 \mathrm{CBB}$ & We11 & Cliff House Sandstone & $75-04-09$ & 5.0 & 6.3 & 1410 & 1040 & 450 & 2.3 \\
\hline 37 & $\mathrm{NB} 03501034 \mathrm{DBC} 1$ & We 11 & Point Lookout Sandstone & $83-07-26$ & 11.5 & 8.9 & 1380 & 923 & 21 & 1.2 \\
\hline 38 & NB03501034DCC 1 & We11 & Menefee Formation & $83-07-28$ & 15.5 & 8.4 & 1650 & 903 & 25 & 1.7 \\
\hline 40 & NB03501114DDC & We11 & Menefee Formation & $74-12-09$ & 6.0 & 6.5 & 335 & 209 & 160 & 2.0 \\
\hline 41 & NB03501123ACC & We11 & Cliff House Sandstone & $75-04-08$ & 6.0 & 7.6 & 330 & 181 & 88 & .6 \\
\hline 42 & NB03501123DAC1 & Well & Cliff House Sandstone & $83-07-29$ & 12.5 & 6.8 & 239 & 135 & 99 & .9 \\
\hline 43 & NB03501128CBB1 & We11 & Alluviun & $83-07-12$ & 9.5 & 7.3 & 1340 & --- & 770 & $\ldots$ \\
\hline 44 & NB03501128DDD 1 & We11 & Menefee Formation & $81-07-15$ & $\ldots$ & -- & --- & 654 & 17 & 2.2 \\
\hline 45 & NB03501128DDD2 & Well & Menefee Formation & $81-07-15$ & $-\cdots$ & -- & --- & 1930 & 40 & 6.2 \\
\hline 46 & NB03501129DBC1 & We11 & Menefee Formation & $75-04-13$ & 10.0 & 6.7 & 950 & 628 & 540 & 4.3 \\
\hline 47 & NB03501131AAA1 & Well & Alluvium & $83-07-08$ & 10.0 & 7.1 & 2450 & --- & 1600 & $\ldots$ \\
\hline 48 & NB03501132ABC & Well & Menefee Formation & $81-07-15$ & $-\cdots$ & $\ldots$ & --- & 1010 & 35 & 5.7 \\
\hline 50 & NBO3501132BBB1 & Well & Alluvium & $83-07-06$ & 12.0 & 6.7 & 4200 & --- & 3200 & $\ldots$ \\
\hline 51 & NB03501132DDD1 & Well & Menefee Formation & $81-07-15$ & $-\cdots$ & -- & --- & 824 & 14 & 2.0 \\
\hline 52 & NB03501132DDD2 & Well & Menefee Formation & $81-07-15$ & --- & -- & --- & 950 & 27 & 4.3 \\
\hline 54 & NBO3400428BDD2 & Spring & Alluvium & $83-08-16$ & 14.0 & 7.2 & 657 & 362 & 260 & 1.4 \\
\hline 56 & NB0350 $1010 \mathrm{CAB} 1$ & Spring & Point Lookout Sandstone & $83-07-28$ & 9.0 & 7.2 & 842 & 555 & 410 & 5.2 \\
\hline 58 & NB03400428DBC 1 & Stream & Cabezon Creek & $83-11-07$ & 10.0 & 8.3 & 540 & 302 & 220 & 1.3 \\
\hline 61 & $\mathrm{NBO} 3400421 \mathrm{CCC} 1$ & Stream & Cabezon Creek & $83-08-16$ & 22.0 & 8.2 & 470 & 263 & 170 & 1.2 \\
\hline 62 & NBO3400421CCC2 & St ream & Cabezon Creek & $83-11-07$ & 10.3 & 8.2 & 512 & 293 & 200 & 1.3 \\
\hline 66 & NBO3 $300432 \mathrm{BCA}$ & Stream & Deep Canyon Creek & $83-08-17$ & 17.5 & 8.3 & 449 & 248 & 160 & .7 \\
\hline 68 & NB03400429BCC 1 & Stream & Stollsteimer Creek & $83-04-22$ & 6.0 & 8.0 & 294 & 200 & 150 & 1.7 \\
\hline 71 & NBO3400430CAA1 & St ream & Stollsteimer Creek & $83-04-22$ & 6.0 & 8.0 & 314 & 226 & 160 & 1.8 \\
\hline 77 & NBO3501126DCD1 & Stream & La Plata River & $83-11-11$ & 5.5 & 7.7 & 185 & 108 & 90 & 1.1 \\
\hline
\end{tabular}


Table 1.--Chemical analyses of water samples from wells, springs, and streams--Continued

$\left[\mu \mathrm{S} / \mathrm{cm}\right.$, microsiemens per centimeter at $25^{\circ} \mathrm{Celsius;} \mathrm{mg/L,} \mathrm{milligram} \mathrm{per} \mathrm{1iter;} \mu g / \mathrm{L}$, microgram per liter; $<$, less than; underlined values exceeded primary public drinking water standards; boldface values exceed secondary public drinking water standards, established by the U.S. Environmental Protection Agency (1977a, 1977b)]

\begin{tabular}{|c|c|c|c|c|c|c|c|c|c|}
\hline $\begin{array}{l}\text { Site } \\
\text { number } \\
\text { (see } \\
\text { figures } \\
2-5 \text { ) }\end{array}$ & $\begin{array}{l}\text { Calcium, } \\
\text { dis- } \\
\text { solved } \\
\text { (mg/L } \\
\text { as Ca) }\end{array}$ & $\begin{array}{l}\text { Magne- } \\
\text { sium, } \\
\text { dis- } \\
\text { solved } \\
\text { (mg/L. } \\
\text { as } \mathrm{Mg} \text { ) }\end{array}$ & $\begin{array}{l}\text { Sodium, } \\
\text { dis- } \\
\text { solved } \\
\text { (mg/L } \\
\text { as } \mathrm{Na} \text { ) }\end{array}$ & $\begin{array}{l}\text { Chlo- } \\
\text { ride, } \\
\text { dis- } \\
\text { solved } \\
\text { (mg/L } \\
\text { as C1) }\end{array}$ & $\begin{array}{l}\text { Fluo- } \\
\text { ride, } \\
\text { dis- } \\
\text { solved } \\
\text { (mg/L } \\
\text { as F) }\end{array}$ & $\begin{array}{c}\text { Alka- } \\
1 \text { inity } \\
\text { lab } \\
(\mathrm{mg} / \mathrm{L} \\
\text { as } \\
\left.\mathrm{CaCO}_{3}\right)\end{array}$ & $\begin{array}{c}\text { Nitro- } \\
\text { gen } \\
\mathrm{NO}_{2}+\mathrm{NO}_{3}, \\
\text { dis- } \\
\text { solved } \\
\text { (mg/L } \\
\text { as } \mathrm{N} \text { ) }\end{array}$ & $\begin{array}{l}\text { Sulfate, } \\
\text { dis- } \\
\text { solved } \\
\text { ( } \mathrm{mg}^{-} / \mathrm{L} \\
\text { as } \mathrm{SO}_{4} \text { ) }\end{array}$ & $\begin{array}{l}\text { Alum- } \\
\text { inum, } \\
\text { dis- } \\
\text { solved } \\
(\mu g / L \\
\text { as } A l)\end{array}$ \\
\hline 1 & 60 & 9.0 & 27 & 4.4 & .50 & 194 & .26 & 54 & 10 \\
\hline 2 & 120 & 11 & 14 & 1.7 & .40 & 245 & .38 & 140 & 10 \\
\hline 3 & 120 & 47 & 35 & 3.8 & .30 & 250 & .39 & 310 & $<10$ \\
\hline 5 & 85 & 14 & 37 & 3.0 & .40 & 280 & .10 & 79 & $<10$ \\
\hline 6 & 72 & 9.6 & 34 & 3.6 & .60 & 224 & $<.10$ & 61 & 100 \\
\hline 7 & 200 & 49 & 43 & 3.5 & .30 & 252 & $<.10$ & 550 & 20 \\
\hline 8 & 58 & 7.8 & 95 & 5.8 & .50 & 350 & .23 & 39 & 50 \\
\hline 10 & 120 & 14 & 37 & 2.4 & .30 & 312 & .27 & 130 & $<10$ \\
\hline 11 & 170 & 55 & 47 & 15 & .40 & 344 & .14 & 230 & 20 \\
\hline 12 & 110 & 38 & 33 & 5.4 & .30 & 270 & .56 & 230 & 30 \\
\hline 13 & 190 & 54 & 42 & 8.6 & .30 & 331 & .30 & 440 & 20 \\
\hline 14 & 99 & 38 & 31 & 8.8 & .30 & 241 & .31 & 230 & 10 \\
\hline 15 & 28 & 4.8 & 180 & 4.6 & .90 & 386 & $<.10$ & 99 & 20 \\
\hline 16 & 230 & 56 & 56 & 22 & .30 & 430 & .65 & 490 & 20 \\
\hline 17 & 100 & 27 & 32 & 7.1 & .40 & 235 & .22 & 190 & 20 \\
\hline 18 & 68 & 9.1 & 25 & 1.3 & .30 & 192 & .56 & 78 & 20 \\
\hline 24 & 5.8 & .9 & 480 & 32 & 1.9 & $-\cdots$ & .01 & 4.3 & -- \\
\hline 25 & 340 & 280 & 300 & 93 & .50 & --- & .27 & 2000 & --- \\
\hline 27 & 59 & 8.0 & 28 & 1.2 & .20 & 228 & .29 & 13 & 10 \\
\hline 28 & 62 & 23 & 200 & 15 & .30 & $\cdots$ & .27 & 220 & -- \\
\hline 29 & 110 & 8.9 & 44 & 7.6 & .40 & --- & 1.1 & 91 & --- \\
\hline 31 & 200 & 82 & 43 & 5.7 & .30 & 236 & .13 & 680 & -- \\
\hline 32 & 44 & 22 & 160 & 10 & .90 & 382 & $<.10$ & 160 & 20 \\
\hline 33 & .6 & .1 & 290 & 4.3 & 1.6 & 608 & $<.10$ & 23 & 10 \\
\hline 34 & 3.1 & 1.4 & 350 & 3.2 & $\overline{4.3}$ & 757 & $<.10$ & 18 & 20 \\
\hline 35 & .8 & .6 & 470 & 28 & 1.7 & $\cdots$ & .01 & 2.9 & -- \\
\hline 36 & 96 & 51 & 170 & 15 & .80 & $\cdots$ & $<.10$ & 480 & -- \\
\hline 37 & 4.1 & 2.7 & 340 & 20 & .60 & 589 & $<.10$ & 150 & 10 \\
\hline 38 & 6.3 & 2.3 & 360 & 7.6 & 1.7 & 829 & $<.10$ & 17 & 100 \\
\hline 40 & 38 & 15 & 10 & 7.4 & .10 & $\cdots$ & .02 & 38 & $\cdots$ \\
\hline 41 & 25 & 6.2 & 31 & 1.5 & .40 & $-\cdots$ & .07 & 32 & --- \\
\hline 42 & 29 & 6.5 & 8.1 & 1.6 & .30 & 102 & $<.10$ & 16 & 10 \\
\hline 43 & 160 & 89 & 40 & 12 & .30 & 299 & $<.10$ & 550 & $\cdots$ \\
\hline 44 & 4.2 & .7 & 273 & 32 & 2.1 & 471 & $-\cdots$ & 57 & $<10$ \\
\hline 45 & 5.0 & 6.9 & 773 & 296 & 1.6 & 1233 & $-\infty$ & 59 & $<10$ \\
\hline 46 & 99 & 72 & 17 & 5.5 & .50 & $\cdots$ & 1.6 & 230 & -- \\
\hline 47 & 310 & 190 & 52 & 100 & .30 & 406 & 4.2 & 1000 & -- \\
\hline 48 & 8.3 & 4.2 & 432 & 10 & 2.6 & 897 & ---- & 16 & $<10$ \\
\hline 50 & 490 & 490 & 92 & 59 & .30 & 657 & 4.4 & 2600 & $\ldots$ \\
\hline 51 & 4.0 & .6 & 364 & 24 & 3.1 & 696 & --- & 11 & $<10$ \\
\hline 52 & 4.7 & 3.6 & 405 & 44 & 3.0 & 770 & $\ldots$ & 25 & $<10$ \\
\hline 54 & 86 & 11 & 24 & 2.1 & .50 & 240 & $<.10$ & 81 & 10 \\
\hline 56 & 70 & 57 & 25 & 3.3 & .10 & 213 & .94 & 250 & $<10$ \\
\hline 58 & 72 & 9.7 & 29 & 2.6 & .60 & 225 & $<.10$ & 41 & $<10$ \\
\hline 61 & 51 & 9.3 & 30 & 2.5 & .60 & 180 & $<.10$ & 49 & $<10$ \\
\hline 62 & 62 & 10 & 29 & 2.9 & .60 & 203 & $<.10$ & 54 & $<10$ \\
\hline 66 & 50 & 9.2 & 30 & 2.8 & .40 & 195 & $<.10$ & 27 & 10 \\
\hline 68 & 42 & 10 & 9.9 & 1.7 & .10 & 108 & $<.10$ & 60 & 200 \\
\hline 71 & 44 & 11 & 12 & 3.7 & .20 & 103 & $<.10$ & 82 & 200 \\
\hline 77 & 28 & 4.8 & 2.3 & .8 & .20 & 73 & .12 & 19 & $<10$ \\
\hline
\end{tabular}


Table 1.--Chemical analyses of water samples from wells, springs, and streams--Continued

l $\mu \mathrm{S} / \mathrm{cm}$, microsiemens per centimeter at $25^{\circ}$ Celsius; mg/L, milligram per 1iter; $\mu$ g/L, microgram per 1 iter;

$<$, less than; underlined values exceeded primary public drinking water standards; boldface values exceed secondary public drinking water standards, established by the U.S. Environmental Protection Agency (1977a, 1977b)]

\begin{tabular}{|c|c|c|c|c|c|c|c|c|c|}
\hline $\begin{array}{l}\text { Site } \\
\text { number } \\
\text { (see } \\
\text { figures } \\
2-5 \text { ) }\end{array}$ & $\begin{array}{l}\text { Arsenic, } \\
\text { dis- } \\
\text { solved } \\
\text { (ug/L } \\
\text { as As) }\end{array}$ & $\begin{array}{l}\text { Cadmium, } \\
\text { dis- } \\
\text { solved } \\
\text { (ug/L } \\
\text { as Cd) }\end{array}$ & $\begin{array}{l}\text { Copper, } \\
\text { dis- } \\
\text { solved } \\
\text { (ug/L } \\
\text { as } \mathrm{Cu} \text { ) }\end{array}$ & $\begin{array}{l}\text { Iron, } \\
\text { dis- } \\
\text { solved } \\
\left(u_{g} / L\right. \\
\text { as } \mathrm{Fe})\end{array}$ & $\begin{array}{l}\text { Lead, } \\
\text { dis- } \\
\text { solved } \\
\text { (ug/L } \\
\text { as } \mathrm{Pb} \text { ) }\end{array}$ & $\begin{array}{c}\text { Manga- } \\
\text { nese, } \\
\text { dis- } \\
\text { solved } \\
\text { (ug/L } \\
\text { as } M n \text { ) }\end{array}$ & $\begin{array}{c}\text { Mercury, } \\
\text { dis- } \\
\text { solved } \\
\text { (ug/L } \\
\text { as } \mathrm{Hg} \text { ) }\end{array}$ & $\begin{array}{l}\text { Molyb- } \\
\text { denum, } \\
\text { dis- } \\
\text { solved } \\
\text { (ug/L } \\
\text { as Mo) }\end{array}$ & $\begin{array}{l}\text { Nickel, } \\
\text { dis- } \\
\text { solved } \\
\text { (ug/L } \\
\text { as } \mathrm{Ni} \text { ) }\end{array}$ \\
\hline 1 & 1 & 2 & 6 & 63 & $<1$ & 55 & $<.1$ & $<1$ & $<1$ \\
\hline 2 & $<1$ & 3 & 1 & 13 & 8 & 26 & $<.1$ & $<1$ & $<1$ \\
\hline 3 & 1 & $<1$ & 3 & 16 & 10 & 2 & $<.1$ & 2 & 1 \\
\hline 5 & $<1$ & 3 & 3 & 1100 & 17 & 260 & $<.1$ & $<1$ & $<1$ \\
\hline 6 & $<1$ & $<1$ & 22 & 120 & $<1$ & 23 & $<.1$ & $<1$ & 1 \\
\hline 7 & 2 & 5 & 19 & 150 & 45 & 380 & $<.1$ & $<1$ & 2 \\
\hline 8 & 1 & 8 & 23 & 29 & 120 & 260 & .1 & $<1$ & 7 \\
\hline 10 & $<1$ & 2 & 7 & 20 & $\overline{2}$ & 17 & $<.1$ & $<1$ & 5 \\
\hline 11 & 5 & $<1$ & 7 & 2200 & $<1$ & 4800 & $<.1$ & $<10$ & 9 \\
\hline 12 & 1 & $<1$ & 2 & 29 & $<1$ & 26 & $<.1$ & $<1$ & 1 \\
\hline 13 & 1 & $<1$ & $<1$ & 330 & $<1$ & 1700 & $<.1$ & $<1$ & 2 \\
\hline 14 & $<1$ & 2 & 6 & 7 & 1 & 14 & $<.1$ & $<1$ & 4 \\
\hline 15 & $<1$ & 2 & 2 & 190 & 4 & 38 & $<.1$ & 12 & $<1$ \\
\hline 16 & 1 & 2 & 10 & 88 & $<1$ & 740 & $<.1$ & $<1$ & 4 \\
\hline 17 & 3 & $<1$ & $<1$ & 78 & $<1$ & 2200 & .1 & $<1$ & $<1$ \\
\hline 18 & $<1$ & $<1$ & 7 & 13 & $B$ & 13 & $<.1$ & $<1$ & 4 \\
\hline 24 & 2 & $\cdots$ & - & 70 & -- & $<10$ & $\ldots$ & $\ldots$ & -- \\
\hline 25 & $<1$ & - & - & 2500 & -- & 1100 & $\ldots$ & -.- & -- \\
\hline 27 & 3 & 1 & 15 & 6 & 8 & 1 & $<.1$ & $<1$ & $<1$ \\
\hline 28 & $<1$ & -- & - & 1500 & -- & 100 & $\cdots$ & $\ldots$ & - \\
\hline 29 & 1 & -- & 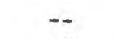 & 20 & -- & $<10$ & -- &.- & -- \\
\hline 31 & $<1$ & $<1$ & 3 & 90 & 2 & 19 & $<.1$ & $<2$ & 17 \\
\hline 32 & 1 & 8 & 1 & 30 & 160 & 12 & $<.1$ & $<2$ & 25 \\
\hline 33 & 1 & $<1$ & $<1$ & 9 & 1 & 3 & .1 & $<2$ & 15 \\
\hline 34 & 1 & 2 & 17 & 680 & 18 & 5 & $<.1$ & $<1$ & $<1$ \\
\hline 35 & $<1$ & -- & -- & 30 & $\ldots$ & $<10$ & $\cdots$ & $\cdots$ & -- \\
\hline 36 & $<1$ & - & - & 20000 & $\cdots$ & 200 & $\cdots$ & 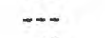 & + \\
\hline 37 & $<1$ & $<1$ & $<1$ & 14 & 3 & 3 & $<.1$ & $<1$ & $<1$ \\
\hline 38 & 1 & $<1$ & $<1$ & 88 & 6 & 11 & $<.1$ & $<1$ & $<1$ \\
\hline 40 & 1 & - & -- & 40 & $\cdots$ & 70 & $\cdots$ & $\cdots$ & $\cdots$ \\
\hline 41 & 1 & - & - & $<10$ & $-\cdots$ & $<10$ & $\cdots$ & $\ldots$ & - \\
\hline 42 & $<1$ & 1 & 1 & 220 & 5 & 14 & $<.1$ & $<1$ & $<1$ \\
\hline 43 & 1 & 3 & $<1$ & 830 & 6 & 710 & $<.1$ & $\cdots$ & $<2$ \\
\hline 44 & $<1$ & $<1$ & $<1$ & $<10$ & $<1$ & 1 & $<.1$ & $<1$ & $<1$ \\
\hline 45 & $<1$ & $<1$ & $<1$ & $<10$ & $<1$ & 2 & $<.1$ & $<1$ & $<1$ \\
\hline 46 & $<1$ & - & -- & $<10$ & $\ldots$ & $<10$ & -- & $-\cdots$ & - \\
\hline 47 & $<1$ & 15 & 3 & 50 & 190 & 1700 & $<.1$ & $\ldots$ & 2 \\
\hline 48 & $<1$ & $\overline{<1}$ & $<1$ & $<10$ & $\overline{<1}$ & $<1$ & $<.1$ & $<1$ & $<1$ \\
\hline 50 & $<1$ & 10 & 5 & 190 & 210 & 1300 & .1 & $\cdots$ & 6 \\
\hline 51 & $<1$ & $<1$ & $<1$ & $<10$ & $<1$ & $<1$ & $<.1$ & $\cdots$ & $<1$ \\
\hline 52 & $<1$ & $<1$ & $<1$ & $<10$ & $<1$ & 2 & $<.1$ & $<1$ & $<1$ \\
\hline 54 & $<1$ & 9 & 1 & 8 & 130 & 13 & $<.1$ & $<1$ & $<1$ \\
\hline 56 & $<1$ & 2 & $<1$ & 5 & 4 & 2 & <. 1 & $<1$ & $<1$ \\
\hline 58 & 1 & 7 & $<1$ & 7 & 35 & 2 & .3 & $<1$ & 1 \\
\hline 61 & 1 & $<1$ & $<1$ & 10 & $<1$ & 2 & $<.1$ & $<1$ & $<1$ \\
\hline 62 & $<1$ & $<1$ & 1 & 5 & $<1$ & $<1$ & 2.1 & $<1$ & $<1$ \\
\hline 66 & 1 & $<1$ & $<1$ & 6 & $<1$ & 1 & $\overline{c .1}$ & $<1$ & $<1$ \\
\hline 68 & 2 & 1 & 3 & 220 & 1 & 11 & $<.1$ & $<1$ & 4 \\
\hline 71 & 2 & 3 & 5 & 250 & 3 & 14 & $<.1$ & $<1$ & 5 \\
\hline 77 & $<1$ & 3 & 4 & 53 & 19 & 19 & .1 & $<1$ & 5 \\
\hline
\end{tabular}


Table 1.--Chemical analyses of water samples from wells, springs, and streams--Continued

$\left[\mu \mathrm{S} / \mathrm{cm}\right.$, microsiemens per centimeter at $25^{\circ}$ Celsius; mg/L, milligram per liter; $\mu g / L$, microgram per liter; $<$, less than; underlined values exceeded primary public drinking water standards; boldface values exceed secondary public drinking water standards, established by the U.S. Environmental Protection Agency (1977a, 1977b)]

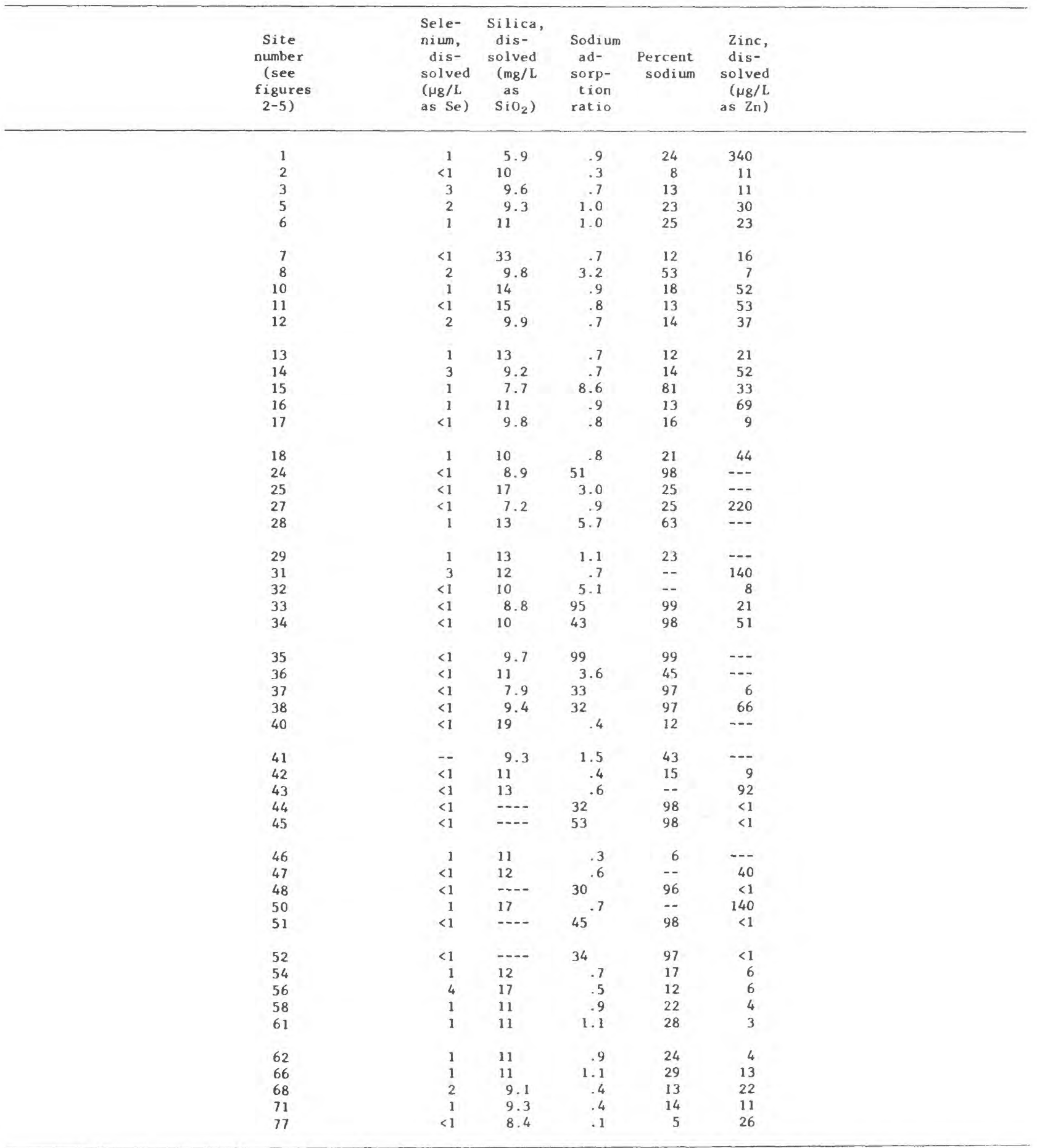


Table 2.--Well information

\begin{tabular}{|c|c|c|c|c|c|c|c|c|c|}
\hline $\begin{array}{l}\text { Sile } \\
\text { number } \\
\text { (see } \\
\text { figs. } \\
2.3 \text {, } \\
\text { and 5) }\end{array}$ & $\begin{array}{l}\text { Well identifier } \\
\text { (see }+1 g .6 \text { ) }\end{array}$ & Owner & $\begin{array}{l}\text { Pruncipal } \\
\text { aquifer }\end{array}$ & $\begin{array}{l}\text { Land } \\
\text { surface } \\
\text { altitude } \\
\text { (feet) }\end{array}$ & $\begin{array}{l}\text { Well } \\
\text { depth } \\
\text { (feet) }\end{array}$ & $\begin{array}{l}\text { Depth to } \\
\text { water } \\
\text { (feet) }\end{array}$ & $\begin{array}{l}\text { Date } \\
\text { water } \\
\text { level } \\
\text { measured }\end{array}$ & $\begin{array}{l}\text { Date } \\
\text { sampled } \\
\text { (see } \\
\text { table 1) }\end{array}$ & Remarks \\
\hline 1 & NB0 $3400428 B D D 1$ & Frere, Lourse & Al luvi um & 6670 & 6.25 & 1.37 & $07 / 19 / 1983$ & $07 / 19 / 1983$ & \\
\hline 2 & $\mathrm{NB} 03400428 \mathrm{DCDI}$ & Ryan International & Fruitland Formation & 6840 & 73.97 & 39.85 & $07 / 12 / 1983$ & $07 / 27 / 1983$ & Uncased core hole. \\
\hline 3 & NBU3400429ACCI & Hamilton, W. E. & Alluvium & 6490 & 59.00 & 30.26 & $07 / 07 / 1983$ & $08 / 16 / 1983$ & \\
\hline 4 & NB03400429CBAI & Martinez, Mel & Fruitland Formation & 6520 & 108.40 & 58.64 & $06 / 27 / 1983$ & - - & Dissolved gases. \\
\hline 5 & NB03400429CBBI & Chimney Rock Coal & Fruitland Formation & 6490 & 47.00 & 32.73 & $07 / 07 / 1983$ & $07 / 15 / 1983$ & \\
\hline 6 & NB03400429CBB2 & Chimney Rock Coal & $\begin{array}{l}\text { Alluvium/Fruitland } \\
\text { Formation }\end{array}$ & 6491 & 67.00 & 45.28 & $11 / 08 / 1983$ & $11 / 08 / 1983$ & Slug tested. \\
\hline 7 & NB03400429CBB3 & Chimney Rock Coal & Fruitland Formation & 6497 & 58.00 & 22.79 & $11 / 08 / 1983$ & $11 / 08 / 1983$ & $\begin{array}{l}\text { Completed below C coal } \\
\text { seam; slug tested. }\end{array}$ \\
\hline 8 & NB03400430ABBL & Chimney Rock Coal & Fruitland Formation & 6707 & 206.00 & 163.00 & $11 / 08 / 1983$ & $11 / 08 / 1983$ & $\begin{array}{l}\text { Double completion in } A, B \text {, } \\
\text { and } C \text { coal seams; slug } \\
\text { tested. }\end{array}$ \\
\hline 9 & NBO3400430ABB2 & Chimney Rock Coal & Fruitland Formation & 6707 & 100.00 & Dry & - & - & $\begin{array}{l}\text { Double completion in } A, B \text {, } \\
\text { and } C \text { coal seams. }\end{array}$ \\
\hline 10 & NBO3400430ACC1 & Chimney Rock Coal & Fruitland Formation & 6472 & 112.78 & 48.49 & $07 / 07 / 1983$ & $08 / 22 / 1983$ & $\begin{array}{l}\text { Completed in A, B, and C } \\
\text { coal seams: Observation } \\
\text { well while NBO3400430DBB2 } \\
\text { was pumped. }\end{array}$ \\
\hline 11 & NBO3400430ACDI & Chimney Rock Coal & Alluvium & 6415 & 12.05 & 2.54 & $07 / 07 / 1983$ & $07 / 20 / 1983$ & \\
\hline 12 & NBO3400430ADC1 & Chimney Rock Coal & Alluvium & 6412 & 45.90 & 11.95 & $07 / 07 / 1983$ & $07 / 15 / 1983$ & $\begin{array}{l}\text { Pumping well depth was } \\
61 \mathrm{ft} \text { in aquifer test. }\end{array}$ \\
\hline 13 & NBO3400430ADC2 & Chimney Rock Coal & Alluvium & 6412 & 12.05 & 10.12 & $07 / 07 / 1983$ & $07 / 15 / 1983$ & $\begin{array}{l}\text { Observation well while } \\
\text { NBO3400430ADC1 was pumped. }\end{array}$ \\
\hline 14 & NBO3400430ADD 1 & Chimney Rock Coal & Alluvium & 6452 & 9.60 & 9.01 & $07 / 07 / 1983$ & $10 / 19 / 1983$ & Dry by $11 / 11 / 83$. \\
\hline 15 & NBO3400430DAAI & Chimney Rock Coal & $\begin{array}{l}\text { Spoil Pile (Fruitland } \\
\text { Formation rubble) }\end{array}$ & 6527 & 123.70 & 106.94 & $07 / 07 / 1983$ & $07 / 27 / 1983$ & \\
\hline 16 & NB03400430DBAI & Chimney Rock Coal & Alluvium & 6405 & 7.33 & 6.52 & $07 / 07 / 1983$ & $07 / 20 / 1983$ & \\
\hline 19 & NB03400430DBCI & Martinez, Mel & Alluvium & 6415 & 55.00 & 19.14 & $07 / 13 / 1983$ & --on- & \\
\hline 20 & NB03400535DDD1 & George, Sharon & Alluvium & 6315 & 59.00 & 22.10 & $06 / 28 / 19 B 3$ & -.......... & \\
\hline 21 & NB0 $3400536 \mathrm{CCB1}$ & Gallegos, John & Alluvium & 6315 & 73.62 & 15.57 & $06 / 23 / 1983$ & - n & USGS observation well. \\
\hline 22 & $\mathrm{NB} 03400536 \mathrm{CCC} 2$ & Wilcox, J. C. & Alluvium & 6310 & $-\cdots$ & 14.13 & $07 / 13 / 1983$ & -....- & \\
\hline 23 & NB03400901CCCI & Erwin, Paul $\mathrm{R}$. & Animas Formation & 6850 & 95.00 & 46.60 & $05 / 31 / 1983$ & - & \\
\hline 24 & NB03401001CCB & Paulek, Grant & Cliff House Sandstone & 6880 & $\cdots-\cdots$ & $\ldots$ & - n-n-n & $12 / 12 / 1974$ & \\
\hline 25 & NB03401206CDA & Boggs, Rodney & Menefee Formation & 6990 & 152.00 & $\ldots$ & n............ & $04 / 10 / 1975$ & \\
\hline
\end{tabular}




\begin{tabular}{|c|c|c|c|c|c|c|c|c|c|}
\hline $\begin{array}{c}\text { Site } \\
\text { number } \\
\text { (see } \\
\text { figs. } \\
2,3 \\
\text { and 5) }\end{array}$ & $\begin{array}{l}\text { Well ident if ser } \\
\text { (see tig. 6) }\end{array}$ & Owner & $\begin{array}{l}\text { Principal } \\
\text { aquifer }\end{array}$ & $\begin{array}{l}\text { Land } \\
\text { surtace } \\
\text { altitude } \\
\text { (feet) }\end{array}$ & $\begin{array}{l}\text { well } \\
\text { depth } \\
\text { (feet) }\end{array}$ & $\begin{array}{l}\text { Depth to } \\
\text { water } \\
\text { (feet) }\end{array}$ & $\begin{array}{l}\text { Date } \\
\text { water } \\
\text { level } \\
\text { measured }\end{array}$ & $\begin{array}{l}\text { Date } \\
\text { sampled } \\
\text { (see } \\
\text { table 1) }\end{array}$ & Kemarks \\
\hline 26 & NB0350061 $7 \mathrm{BAB1}$ & Hoover, Bryan B. & Lewis Shale & 7600 & 109.00 & 21.90 & $06 / 16 / 1983$ & -n-n- & \\
\hline 27 & NB03500803CAA1 & Seyfarth, Jay $F$. & Cliff House Sandstone & 7380 & 147.00 & 9.10 & $06 / 30 / 1983$ & $07 / 29 / 1983$ & \\
\hline 28 & NBO3500808CCB1 & Engler, Robt. & $\begin{array}{l}\text { Point Lookout } \\
\text { Sandstone }\end{array}$ & 7275 & 102.00 & 17.72 & $08 / 02 / 1983$ & $12 / 12 / 1974$ & \\
\hline 29 & NBO3500819BCD & Palmer, Terry & Kirtland Shale & 7070 & 100.00 & ---- & -..--n-..- & $04 / 15 / 1975$ & \\
\hline 30 & NB03501028ADC1 & Wehner, Leo & Menefee Formation & 7440 & 450.00 & 377.90 & $06 / 07 / 1983$ & n & \\
\hline 31 & NB03501028CDAI & LaPlata Vista & Menefee Formation & 7290 & 48.50 & 7.60 & $06 / 09 / 1983$ & $06 / 08 / 1983$ & \\
\hline 32 & NB03501028CDA2 & LaPlata Vista & Menefee Formation & 7290 & 465.00 & 137.60 & $06 / 09 / 1983$ & $06 / 08 / 1983$ & \\
\hline 33 & NB03501028DCCl & LaPlata Vista & Menefee Formation & 7320 & 580.00 & 239.40 & $06 / 08 / 1983$ & $06 / 08 / 1983$ & \\
\hline 34 & NB03501028DDBI & Bird, G. & Menefee Formation & 7440 & 490.00 & 148.00 & $06 / 07 / 1983$ & $07 / 26 / 1983$ & \\
\hline 35 & NB03501034BBC & Kneippl, Stephen & Menefee Formation & 7445 & 466.00 & 270.00 & $\cdots+\cdots$ & $04 / 08 / 1975$ & \\
\hline 36 & NB03501034CBB & Capp, Clifford & Cliff House Sandstone & 7300 & 138.00 & 79.00 & $04 / 09 / 1975$ & $04 / 09 / 1975$ & \\
\hline 37 & NB03501034DBC1 & Harrell, Lynn & $\begin{array}{l}\text { Point Lookout } \\
\text { Sandstone }\end{array}$ & 7280 & 440.00 & 82.70 & $06 / 06 / 1983$ & $07 / 26 / 1983$ & \\
\hline 38 & $\mathrm{NB} 03501034 \mathrm{DCC} 1$ & Gibson, Dan $F$. & Menefee Formation & 7200 & 259.00 & 78.00 & $07 / 28 / 1983$ & $07 / 28 / 1983$ & \\
\hline 39 & NB03501114CAD1 C & Gitile, walter & Menefee Formation & 8315 & 76.50 & 45.60 & $06 / 02 / 1983$ & $+\cdots$ & \\
\hline 40 & NB03501114DDC & Carl, Larry & Menefee Formation & 8075 & 86.00 & 9.00 & $12 / 09 / 1974$ & $12 / 09 / 1974$ & \\
\hline 41 & NB03501123ACC & $\begin{array}{l}\text { Hesperus Baptist } \\
\text { Camp }\end{array}$ & Cliff House Sandstone & 8030 & 76.00 & 25.00 & $04 / 08 / 1975$ & $04 / 08 / 1975$ & \\
\hline 42 & NB03501123DACI & Demarest, Donald & Cliff House Sandstone & 7980 & 62.00 & 13.00 & $05 / 01 / 1983$ & $07 / 29 / 1983$ & \\
\hline 43 & NB03501128CBBI & Pfledging, Phillip & Alluvium & 7510 & 7.80 & 6.26 & $07 / 12 / 1983$ & $07 / 12 / 1983$ & \\
\hline 44 & NBO3501128DDDI r & Massey Coal Co. & Menefee Formation & 7860 & 345.00 & 291.00 & $07 / 21 / 1983$ & $07 / 15 / 1981$ & $\begin{array}{l}\text { Double completion } \\
\text { (sandstone). }\end{array}$ \\
\hline 45 & NB03501128DDD2 & Massey Coal Co. & Menefee Formation & 7860 & 318.90 & 299.00 & $07 / 21 / 1983$ & $07 / 15 / 1981$ & $\begin{array}{l}\text { Double completion } \\
\text { (coal). }\end{array}$ \\
\hline 46 & $\mathrm{NBO} 03501129 \mathrm{DBCl}$ & Sun Belt Mining & Menefee Formation & 7470 & 57.00 & 40.00 & $04 / 13 / 1975$ & $04 / 13 / 1975$ & \\
\hline 47 & NB03501131AAA1 & $\begin{array}{l}\text { Hunt ington, } \\
\text { Lawrence }\end{array}$ & Alluvium & 7360 & 13.50 & 0.80 & $07 / 08 / 1983$ & $07 / 08 / 1983$ & $\begin{array}{l}\text { Well developed from a } \\
\text { spring. }\end{array}$ \\
\hline 48 & NB03501132ABC1 & Massey Coal Co. & Menefee Formation & 7780 & 338.00 & 318.00 & $07 / 21 / 1983$ & $07 / 15 / 1981$ & $\begin{array}{l}\text { Double completion } \\
\text { (sandstone). }\end{array}$ \\
\hline 49 & NB03501132ABC2 & Massey Coal Co. & Menefee Formation & 7780 & 300.00 & 294.00 & $07 / 21 / 1983$ & 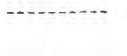 & $\begin{array}{l}\text { Double completion } \\
\text { (coal). }\end{array}$ \\
\hline 50 & NB03501132BBB1 & $\begin{array}{l}\text { National King } \\
\text { Coal Co. }\end{array}$ & Alluvium & 7390 & 80.00 & 13.26 & $07 / 06 / 1983$ & $07 / 06 / 1983$ & \\
\hline 51 & NB0 $3501132 \mathrm{DDD} 1$ & Massey Coal Co. & Menefee Formation & 7680 & 348.00 & 283.00 & $07 / 21 / 1983$ & $07 / 15 / 1981$ & $\begin{array}{l}\text { Double complet ion } \\
\text { (sandstone). }\end{array}$ \\
\hline 52 & NB03501132DDD2 & Massey Coal Co. & Menefee Formation & 7680 & 318.00 & 302.00 & $07 / 21 / 1983$ & $07 / 15 / 1981$ & $\begin{array}{l}\text { Double completion } \\
\text { (coal). }\end{array}$ \\
\hline
\end{tabular}




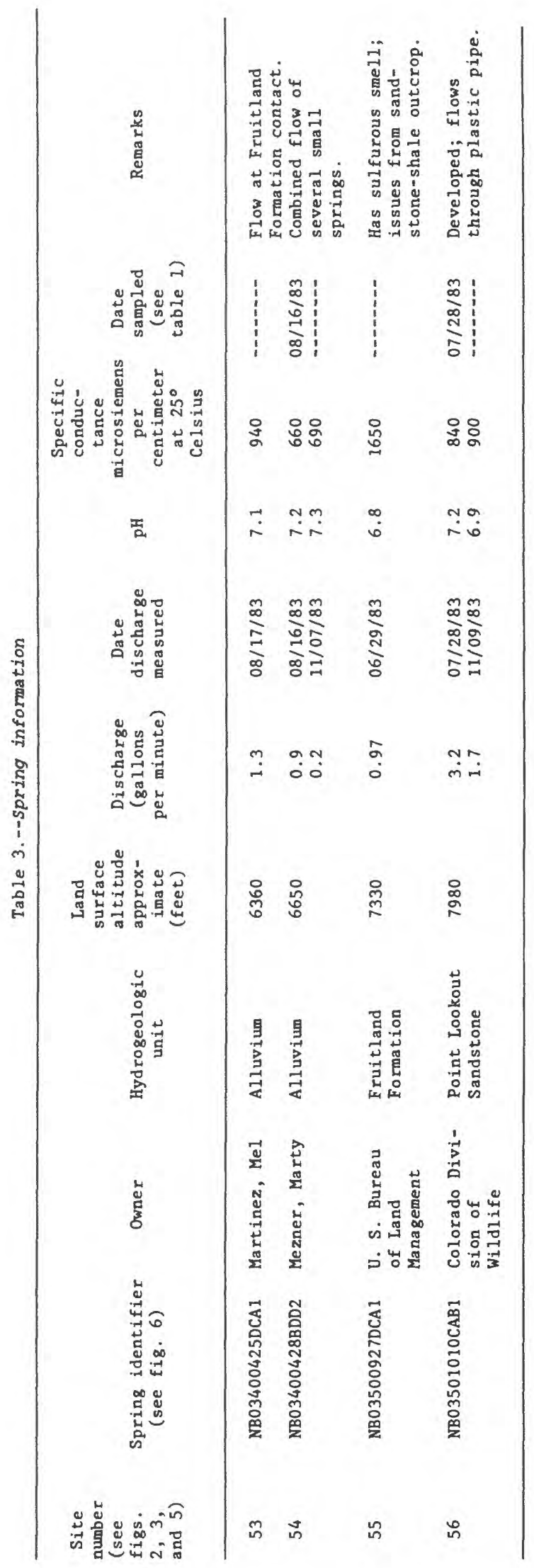




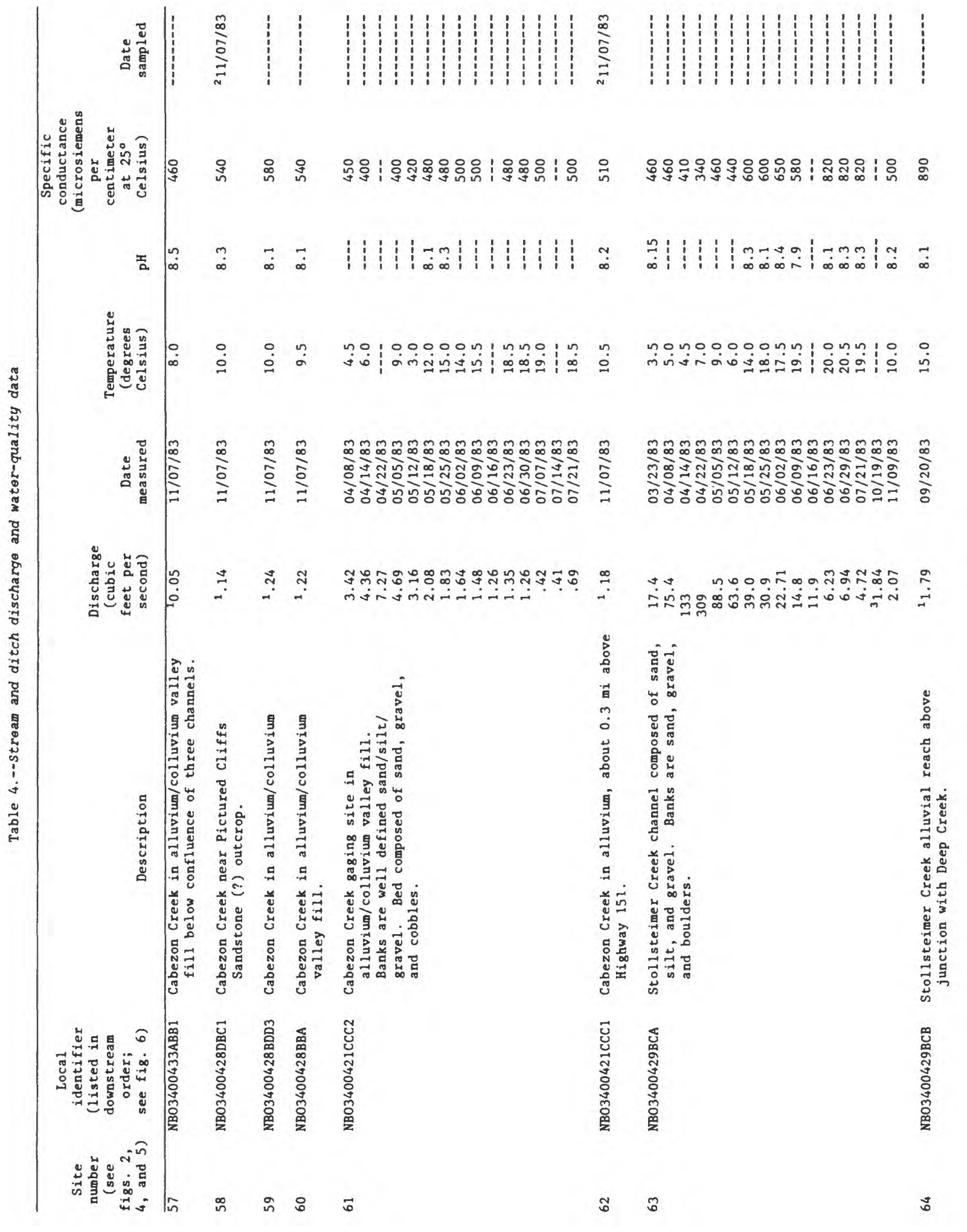




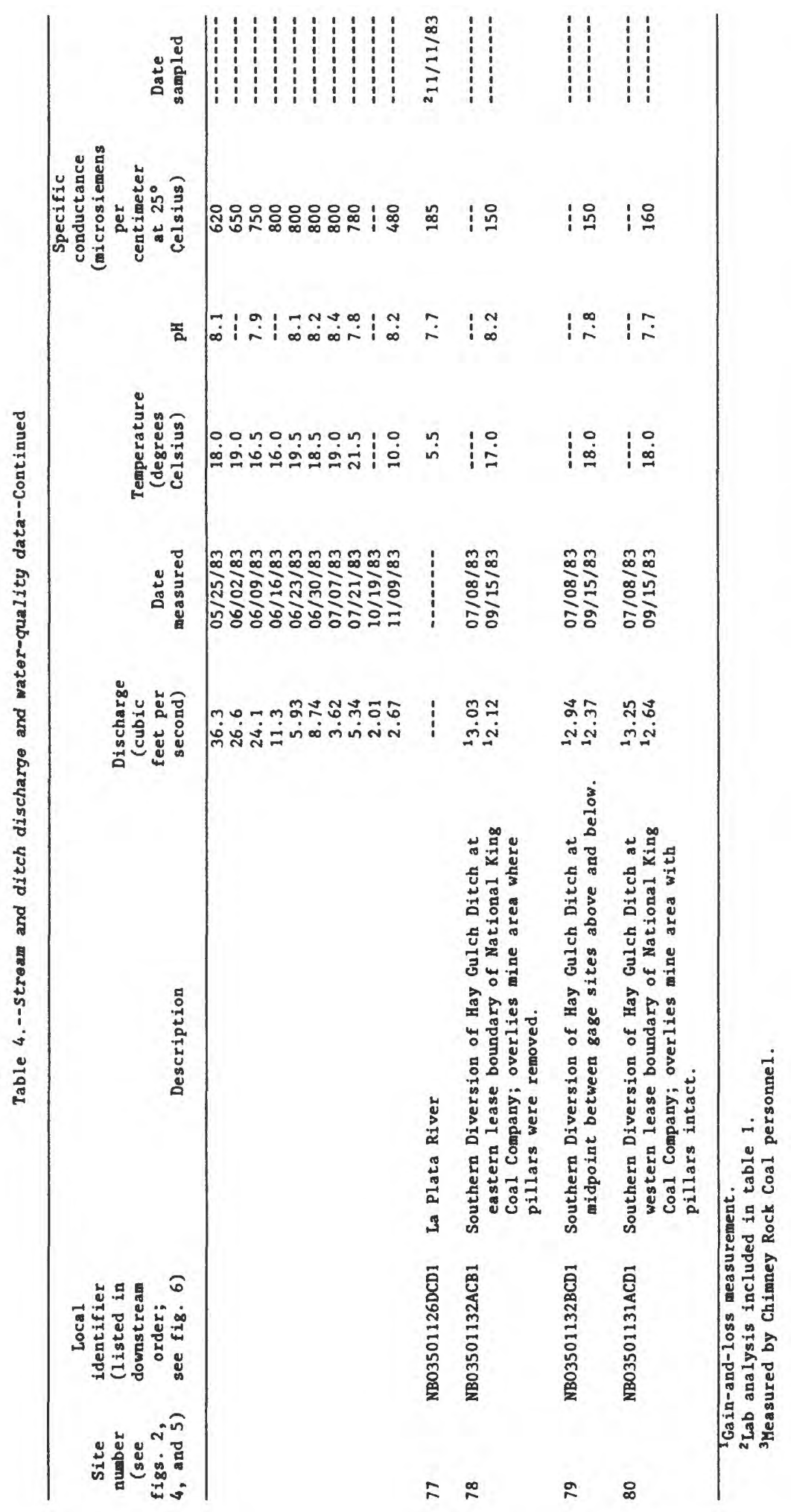




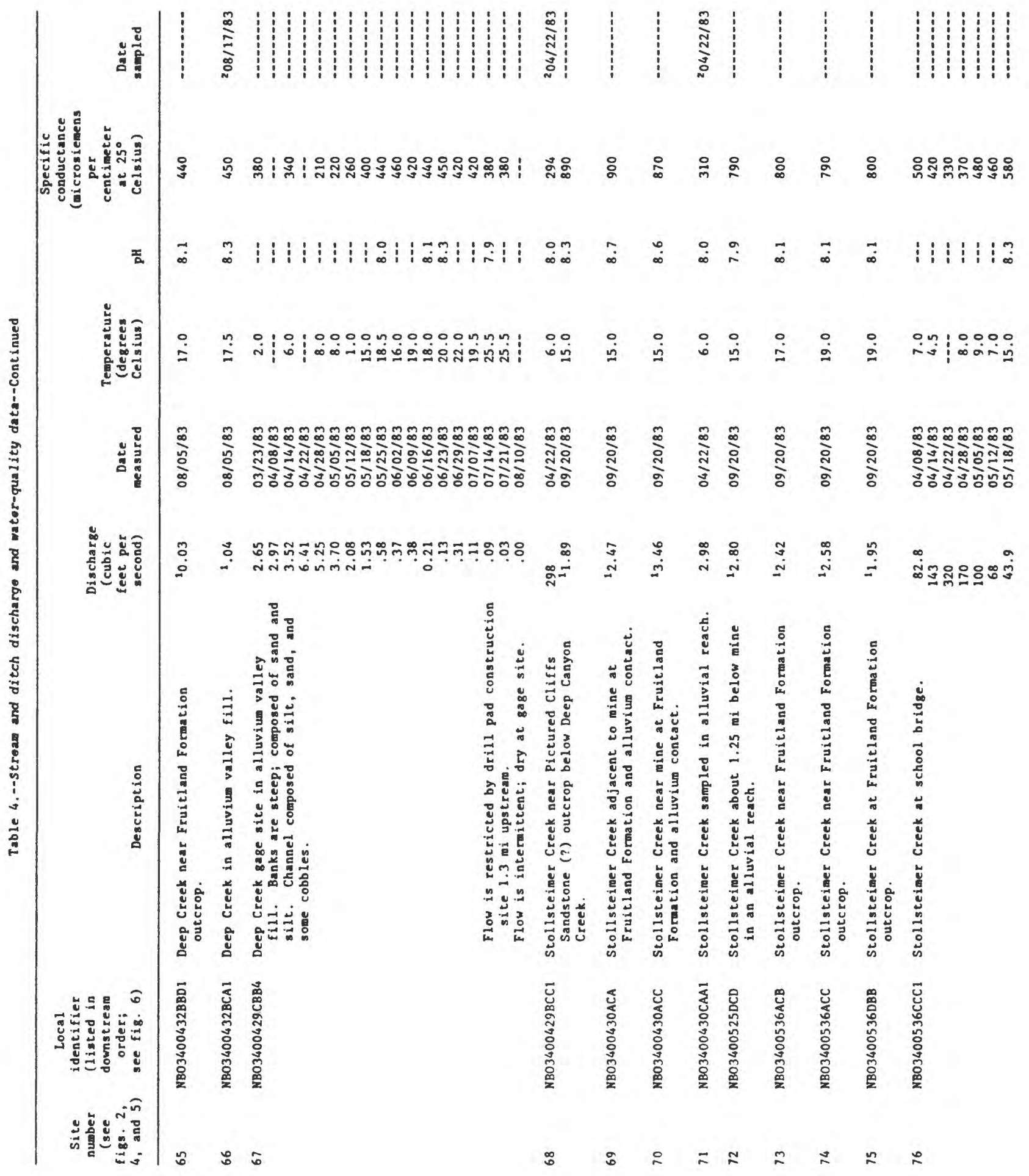

